NBER WORKING PAPER SERIES

\title{
THE LABOR MARKET IMPACT OF EMPLOYER HEALTH BENEFIT MANDATES: EVIDENCE FROM SAN FRANCISCO'S HEALTH CARE SECURITY ORDINANCE
}

\author{
Carrie H. Colla \\ William H. Dow \\ Arindrajit Dube \\ Working Paper 17198 \\ http://www.nber.org/papers/w17198 \\ NATIONAL BUREAU OF ECONOMIC RESEARCH \\ 1050 Massachusetts Avenue \\ Cambridge, MA 02138 \\ July 2011
}

We acknowledge funding support from the Robert Wood Johnson Foundation, the University of California Labor and Employment Research Fund, and the California Program on Access to Care. The views expressed herein are those of the authors and do not necessarily reflect the views of the National Bureau of Economic Research.

NBER working papers are circulated for discussion and comment purposes. They have not been peerreviewed or been subject to the review by the NBER Board of Directors that accompanies official NBER publications.

(C) 2011 by Carrie H. Colla, William H. Dow, and Arindrajit Dube. All rights reserved. Short sections of text, not to exceed two paragraphs, may be quoted without explicit permission provided that full credit, including $(\subset$ notice, is given to the source. 
The Labor Market Impact of Employer Health Benefit Mandates: Evidence from San Francisco's Health Care Security Ordinance

Carrie H. Colla, William H. Dow, and Arindrajit Dube

NBER Working Paper No. 17198

July 2011

JEL No. I18,J2,J3

\begin{abstract}
A key issue surrounding employer benefit mandates is the incidence on workers through wages and employment. In this paper, we address this question using a pay-or-play policy implemented in San Francisco in 2008 that requires employers to either provide health benefits or contribute to a public option health plan. We estimate the impact on employment and earnings for the private sector overall, as well as for high impact sectors: retail and accommodation and food services. We develop a novel approach for individual case studies by combining both spatial discontinuity in policies and permutation-type inference using other MSAs. We find that, compared to control counties, employment and earnings patterns in San Francisco did not change appreciably following the policy. This was true for industries most affected by the mandate, as well as for overall private sector employment. The results are generally robust to inclusion of different control groups, county-specific time trends, and varying pre-periods. In contrast to the small effects on the labor market, we do find that about $25 \%$ of surveyed restaurants imposed customer surcharges, with the median surcharge being $4 \%$ of the bill. These results indicate that while little of the burden of the mandate fell on San Francisco workers, approximately half of the incidence of the mandate fell on consumers.
\end{abstract}

Carrie H. Colla

The Dartmouth Institute for

Health Policy and Clinical Practice

Dartmouth Medical School

35 Centerra Parkway

Lebanon, NH 03766

carrie.colla@dartmouth.edu

William H. Dow

University of California, Berkeley

School of Public Health

239 University Hall, \#7360

Berkeley, CA 94720-7360

and NBER

wdow@berkeley.edu
Arindrajit Dube

Department of Economics

1030 Thompson Hall

University of Massachusetts Amherst

Amherst, MA 01003

and IZA

adube@econs.umass.edu 


\section{Introduction}

Employer mandates to provide health benefits have become increasingly popular mechanisms for insurance coverage expansion, and are incorporated into many health reform proposals, including the U.S. Patient Protection and Affordable Care Act. Mandates of this type are popular because they allow policy makers to finance social policy without government funds, and in the case of a "pay-or-play" mandate such as the one in the Affordable Care Act, raise money from employers to finance coverage expansion. Economic theory and past research have suggested that in demographically identifiable groups who value the benefit at its cost, the incidence of such a mandate is likely to affect workers through reductions in wages or jobs (Gruber 1994, Summers 1989). Wage adjustment and employment effects hinge on employee valuation of the benefit and features of the labor market, such as the minimum wage or collective bargaining agreements. In addition to being of interest at a theoretical level, the impact of an employer mandate to provide health benefits is of policy relevance and the likely effect of the Affordable Care Act on jobs has been politically controversial (Pear 2011).

In late 2006, San Francisco enacted ambitious healthcare legislation with a goal of attaining universal access to health care for the city's residents. As part of the initiative, San Francisco implemented a "pay-or-play" employer mandate to finance health care for residents. This law provides a natural experiment to estimate how the labor market (employment and earnings) responds to a pay-or-play mandate.

Beginning in 2008, the San Francisco Health Care Security Ordinance mandates firms with more than 20 employees to spend a minimum contribution per worker-hour on health benefits. Employers with 100 or more employees were required to contribute $\$ 1.76$ per hour in health spending for each employee in 2008 (with subsequent annual increases of about 5\%) while for smaller firms between 20 and 99 employees the hourly requirement was $\$ 1.17$ (San Francisco OLSE website 2009). This benefit represented a 13-19\% increase over San Francisco's 2008 minimum wage of $\$ 9.36$, so it is a substantial requirement-more stringent than the requirements in the Affordable Care Act or the employer "fair share" requirement that began in Massachusetts in 2007. It is similar in magnitude to the mandate in Hawaii (although Hawaii is not a pay-or-play mandate). Employers can meet this requirement by paying for insurance directly, paying into medical reimbursement accounts, or by paying into the city's "Healthy San 
Francisco" public option, which offers heavily subsidized access to care. ${ }^{1}$ Colla, Dow and Dube (2011) found that although more than $90 \%$ of San Francisco firms with 20 or more employees offered insurance prior to implementation of the law, about $75 \%$ of firms needed to increase health spending to meet the Ordinance's requirements. The same study found that many firms chose to "play" by expanding benefit generosity, but about $18 \%$ of firms chose to "pay" into the city's Healthy San Francisco public option for at least some of their employees. The present paper builds on this research to estimate the impact of these changes in health benefits on jobs, earnings, and cost to consumers over the first 27 months of implementation.

One problem with case studies of policies affecting few units (in this case, one county) is the difficulty of constructing reliable control groups and forming credible inference. In this paper, we develop a novel approach to address both of these problems by merging recent methodological developments - a spatial discontinuity design, and permutation-type inference as developed by Conley and Taber (2011). Thus we include plausible local controls (e.g., Card and Krueger 1996, Dube, Naidu and Reich 2007) while addressing the problem of improper inference (Donald and Lang 2007). We use a spatial discontinuity approach to identify the effects of the employer mandate on labor market outcomes, comparing San Francisco to other counties within the broader metropolitan area. The Conley-Taber approach to inference uses asymptotic approximations that let the number of control units grow large, while the number of treated units remains small. Thus, we consider other top 25 metro areas to account for the possibility of differential trends by city center and peripheries and to consistently estimate the distribution of the treatment effect.

In general, we rule out all but small effects on overall private sector employment and earnings, even after more than two years of mandate implementation. We also consider highimpact sectors such as retail and accommodation and food services, and further consider restaurants as a subsector with particularly large treatment intensity. In all cases, the point estimates are close to zero or positive, and in most cases the Conley-Taber confidence intervals rule out employment or earnings declines of more than one percent. While we cannot rule out the

\footnotetext{
1 San Francisco's mandate varies from the traditional definition of a "pay-or-play" mandate and the federal Affordable Care Act in that the "pay" portion directly benefits the employee and is not general tax revenue. The distinction is relevant for the legal question of which mandates are preempted by ERISA. In this paper, we use the terms "pay-or-play mandate" and "employer health benefit mandate" interchangeably.
} 
null hypotheses of full or no pass-through in the overall private sector-simply because the compliance costs across all firms are so low-we find that only $\$ 0.08$ per hour $(12 \%$ of the industry gap in spending at baseline) is passed through to earnings in a high impact sector like the restaurant industry, and we can statistically rule out pass-through of more than $\$ 0.16$ per hour (26\% pass-through of the gap).

The low pass-through to wages in the restaurant industry is likely due to a combination of a relatively high proportion of workers close to the minimum wage, and the potential for passthrough to consumer prices. In a survey that we conducted of San Francisco restaurants, we found many establishments had instituted a specific surcharge (a line item on the bill, rather than simply increased menu prices) to cover the cost of the mandate. This surcharge-typically around $4 \%$ of the bill—could cover the entire required health spending level for an average restaurant even if it had zero health spending previously. When we take into account that many restaurants already provided some level of health benefit spending, restaurant price surcharges are estimated to account for about $51 \%$ of the required spending increases, suggesting substantial pass-through to consumers at least in this local service sector.

The remainder of the paper is structured as follows. Section 2 discusses the economics of employer mandates and the specifics of the San Francisco law, while Section 3 surveys the existing empirical evidence. Section 4 presents our methodology and data sources, and our results are discussion in Section 5. Section 6 concludes.

\section{The Economics of Employer Mandates}

A simple supply and demand framework is a useful starting point for analyzing the effects of an employer mandate to provide health benefits on the labor market (Summers 1989). A benefit mandate such as the Health Care Security Ordinance will cause the labor demand curve to shift in by the cost of the mandated benefit and the labor supply curve to shift out by an amount equal to the value of the benefit to employees. While we may not expect nominal wages to fall among previously employed workers (Kahn 1997), in a competitive market, the real wage is expected to fall over time through slower wage growth for existing workforce and lower wages for new employees. 
The magnitude and timing of the wage change, and the effect of the mandate on employment, will depend on workers' valuation of the mandated benefit. If employers choose to pay into Healthy San Francisco, it provides the workers family with access to a medical home that coordinates health care delivery in clinics and hospitals in the city. Enrollees with incomes under 300 percent of the federal poverty level whose employers pay into the program have heavily subsidized access (with waived program fees), and those with higher incomes may buy into Healthy San Francisco at rates substantially lower than what they would pay for an individual policy in the private-insurance market (Healthy San Francisco website 2009). For workers at the minimum wage, there cannot be any wage pass-through. At the minimum wage, the joint (employer and employee) surplus from paying into the city option is positive for most workers due to the subsidies up to $300 \%$ of the federal poverty limit. For higher wage workers, who are more likely to have family income greater than 3 times the poverty limit, the subsidy (and hence value of program to the employee) is smaller due to increased program fees for those with income above this level. Therefore, we might expect the largest amount of wage passthrough to occur for jobs paying greater than — but not too much greater than-the minimum wage.

To the extent that workers do not value the benefit at its cost or if the minimum wage is binding, the entire cost of the benefit will not be passed through to wages. If a wage adjustment is not sufficient to offset the cost of the spending mandate, the total compensation of these workers may rise above their marginal value product, leading to a reduction in the number of employees (or possibly a reduction in the hours worked among existing employees, but employee fixed costs may make this less likely). Thus, neoclassical theory predicts some combination of slower wage growth and decreased employment. To investigate the minimum wage floor effect, Table 1 indicates that $18 \%$ of San Francisco workers earned under $\$ 10$ per hour in 2007 (compared to 2008 minimum wage of \$9.36). But using the 2008 Bay Area Employer Health Benefits Survey we further estimate that only 3-5\% of workers were both paid the minimum wage and did not have health benefits in 2007, just prior to implementation of the Health Care Security Ordinance. Thus the minimum wage could only impose a constraint on pass-through for a small portion of workers, although it could have a larger effect on some highly impacted industries (such as restaurants) that have higher proportions of workers at minimum wage and with low baseline insurance coverage. Finally, to the extent that there may 
be labor market frictions, we may expect an increase in compensation to reduce vacancies and/or profits in the short run, rather than observed wages and employment.

An additional potential margin of adjustment is in output product prices. Particularly in markets where full wage pass-through does not occur, and to the extent that the product market is at least partly segmented locally as is the case for local service industries, firms may be able to pass the additional labor costs onto consumers through price increases. The ability of restaurants to pass through additional input costs to consumers depends partly on the price elasticity of demand for restaurants. Estimated price elasticities of demand for restaurant food have varied from inelastic (0.18, Brown 1990) to quite elastic (1.63, Frank and Bernanke 2003 or 2.3, Anderson 2006). Restaurants have many substitutes, including grocery store food, but many of their close substitutes in this case (e.g. fast food) would have received the same supply shock, which could allow pass-through to output prices if the demand elasticities are low enough.

Finally, there could be general equilibrium effects shifting employment between firms. A majority of San Francisco firms with more than 20 workers offered health benefits to some workers prior to the mandate going into effect. These firms were already competing profitably with the non-offering firms prior to the mandate. If there are employment losses in baseline nonoffering firms, some of the baseline offerers may be able to profitably expand to capture their business, thus mitigating employment losses in the aggregate.

\section{Existing Evidence on Employer Mandates}

To date, only a handful of empirical studies have examined the effect of health insurance mandates on wages and employment. Hawaii and Massachusetts are the only states with a mandate for employers to provide health insurance, although Massachusetts' employer mandate is fairly minimal at $\$ 295$ per year and thus should not have substantial labor market effects. The Hawaiian Prepaid Health Care Act of 1974 is an insurance mandate (without any "pay" option) requiring employers to provide insurance to employees, and is thus more similar in magnitude to San Francisco's health spending mandate. Thurston (1997) found that between 1970 and 1990, the Hawaiian industries most affected by the insurance mandate had slower wage growth than other Hawaiian industries (but more rapid wage growth than the same industries nationally). Buchmueller, DiNardo, and Valletta (2009) found that relative wages in Hawaii did fall over a 
longer time period, but the effect was insignificant and the law did not reduce employment probabilities. However, they found a greater reliance on exempt workers (such as those working less than 20 hours per week), suggesting some distortionary labor market effects.

There is a larger set of studies that have analyzed mandates that apply to the benefit makeup of private insurance packages, rather than mandating the offer of insurance. Benefit mandate laws vary from state to state, with a few mandated benefits at the federal level. Early cross-sectional wage studies typically found that the presence of health insurance increased wages, not supporting the compensating differentials hypothesis (e.g. Monheit et al. 1985). However, a key omitted variable in the cross-sectional case is worker productivity, which is difficult to fully control for with observables. The most influential study on the effect of benefit mandates is Gruber (1994), who used a natural experiment to study the effect of state maternity mandates on wages. He found that demographically identifiable affected cohorts (single and married women aged 20 to 40 and married men in the same age range) paid the full cost of the mandates through reductions in wages.

Effects of workers compensation insurance mandates on wages and employment are also relevant to the study of benefit mandates. Empirical studies have examined the effects of workers compensation mandates on wages and found that most (83-100\%) of the expected cost was borne by workers in the form of lower wages, and that the reduction in wages for employees at small firms could be greater (Gruber and Krueger 1991, Viscusi and Moore 1987). In terms of employment levels, Gruber and Krueger also found that higher workers compensation insurance costs had a negative but statistically insignificant effect on employment, with an implied elasticity of labor demand of about -0.5 . Kaestner (1996) examined the effect of unemployment compensation insurance taxes and workers' compensation insurance mandates on the employment of youths and young adults and found that increases in labor costs reduced employment in teenagers, but not young adults.

A parallel body of research is that of effects of minimum wage laws on equilibrium employment levels. Yelowitz (2004) suggests that a health care spending mandate would lead to increased unemployment for workers at the minimum wage. However, a body of evidence from the minimum wage literature suggests that modest increases in labor costs may not lead to noticeable changes in overall staffing patterns (Brown 1999, Card and Krueger 1994, Card and 
Krueger 2000). Dube, Naidu and Reich (2007) found no discernable minimum wage impact on employment in the restaurant sector in San Francisco. Generalizing the border-discontinuity method, Dube, Lester and Reich (2010) estimated the effect of minimum wage changes across all cross-border contiguous county pairs over the 1990-2006 period, and found no disemployment effects in restaurants or other low-wage sectors.

Past research indicates that as health costs rise, firms substitute hours per worker for the number of workers employed (Cutler and Madrian 1998). However, this effect was not found in Hawaii and may not be applicable in this case given that the minimum spending requirements are based on the number of hours the employee works (Thurston 1997).

\section{Data and Research Design}

\subsection{Data and Sample Construction}

In order to investigate the effect on jobs and wages empirically, we use the Quarterly Census of Employment and Wages (QCEW), which is a near census of the working population. We compare employment and weekly earnings trends in San Francisco to those of neighboring counties and to other large metropolitan statistical areas in the United States that did not implement any comparable new employer mandate. Quarterly data on employment and earnings at county-by-quarter-by-industry level were obtained for the period between first quarter of 1990 and first quarter of 2010 from the Bureau of Labor Statistics (BLS). The dataset is based on ES202 filings that every establishment is required to submit quarterly for the purpose of calculating payroll taxes related to unemployment insurance. Since 98 percent of workers are covered by unemployment insurance, the QCEW constitutes a near-census of employment and earnings. Our two primary outcome measures are total employment and average earnings. The earnings measure is the average rate of weekly pay for workers by industry. BLS divides the total payroll in each industry and county in a given quarter by the total employment level in each industry and county for that quarter, and then reports the average weekly earnings on a quarterly basis. The QCEW does not report hours worked. However, we can partly address the possibility of an hour reduction, such as that claimed by the Golden Gate Restaurant Association (Mandelbaum 2009) by examining weekly earnings. To reduce influence of outliers, we imputed data for outliers that were more than four standard deviations away from the mean over the full sample period. 
We chose to focus our attention on all private sector (NAICS code 10), as well as industries most affected by the employer mandate for the years 2002-2010: Retail Establishments (NAICS codes 44-45, 9\% of private employment in 2009), Accommodation and Food Services (72, 14\% of private employment), and its major subsector Eating and Drinking Places (722, 10\% of private employment). ${ }^{2}$ Using data from the 2008 Bay Area Employer Health Benefits Survey, Colla, Dow, and Dube (2011) estimated the "gap" amount per worker hour that the average firm in each industry would need to increase health spending from 2007 to 2008 in order to come into compliance with the minimum spending mandate. The gap reflects a combination of a small percent of firms who did not offer health benefits at all at baseline, other firms that offered benefits but not to all classes of employees covered by the mandate, firms with incomplete takeup of insurance offering, and firms whose benefits are not sufficiently generous to meet the per person spending mandate. On average across all private industries, firms with 20 or more workers would need to increase hourly spending by $\$ 0.29$ per worker (Table 1). Those in retail (Standard Industrial Classification (SIC) 23, 53, 54, 56, 59) would have to increase their health spending by $\$ 0.41$ per worker-hour, those in Accommodation and Food Services (SIC 20, 54, 58, 70) would have to increase spending by $\$ 0.57$, while restaurants (SIC 58) in particular would have to increase their health spending by $\$ 0.62$ per worker-hour. ${ }^{3}$ The additional mandated costs are modest overall, but sizeable in low wage sectors which typically provide limited health benefits to employees. In Table 1, we also report these additional hourly "gap" expenditures (calculated from 2008 Bay Area Employer Health Benefit Survey) as a fraction of wages, using hourly wage by industry in San Francisco from the 2007 American Community Survey (Ruggles et al. 2008).

Additionally, the industries on which we focus have substantial proportions of minimum wage workers, for whom possible disemployment effects may be more of a concern since their wages cannot adjust. According to the 2007 American Community Survey, in San Francisco approximately $45 \%$ of workers in eating and drinking places, 39\% in accommodation and food services, and $26 \%$ of workers in San Francisco retail were paid below $\$ 10$ per hour, which is a close proxy for the minimum wage (Table 1).

\footnotetext{
${ }^{2}$ We use the terms "eating and drinking establishments" and "restaurants" interchangeably throughout the paper.

${ }^{3}$ The gaps presented in Table 1 are smaller than those reported in Colla, Dow and Dube (2011). This is due to incorporation of updated information in gap calculations, such as new data on workers who waived the required spending due to other qualifying coverage.
} 
We term San Francisco the "center" county and used data on four "periphery" counties surrounding San Francisco as a local control group (Alameda, Contra Costa, Marin, and San Mateo counties). We similarly constructed center and periphery counties in other comparable MSAs based on CBSA definitions for the 25 largest MSAs in the U.S. We chose to use the 25 largest MSAs because San Francisco is the $13^{\text {th }}$ largest in the country, producing an equal number of MSAs in the sample that are larger and smaller than San Francisco. We define a "center county" to be a county that encompasses the urban center of the MSA. A list of MSAs, the number of counties by MSA, and definitions of the center counties can be found in Appendix I.

In this paper, we focus on the 2002 to 2010 period. In years before 2002, some counties in the dataset did not have data available for the accommodation and food services and eating and drinking places industries. In addition, during the 2002-2007 pre-period, outcomes in the surrounding counties tracked San Francisco fairly closely, whereas considering longer preperiods led to greater divergence for some outcomes. In a second set of specifications, we consider an even narrower pre-period (2006-2007) to reduce the impact of time-varying heterogeneity. We do show longer trends for our sample counties from 1990 to 2010 in Appendix II.

In order to account for trends in the housing industry between different areas, we control for median housing price and housing sales, contemporaneously and lagged one year using data purchased from Dataquick. Originally, 33\% of county-quarter observations were missing data on sales and 38\% were missing median price. We estimated prices using median loan data, and then used interpolation and extrapolation from neighboring counties to impute missing data elements. We also use population data from the U.S. Census.

One possible threat to our identification is due to changes in the minimum wage between treatment and control areas. The minimum wage in San Francisco increased several times during the years studied, from $\$ 8.82$ in 2006 to $\$ 9.14$ in 2007, $\$ 9.36$ in 2008, and $\$ 9.79$ in 2009. The periphery counties surrounding San Francisco were subject to the California state minimum wage, which increased from $\$ 6.75$ in 2006 to $\$ 7.50$ in 2007 to $\$ 8.00$ in January 2008. The U.S. minimum wage also increased during 2007-2009. We control for the relevant county level minimum wage - based on national, state, and local minimum wage data from the Department of 
Labor. This helps us identify the San Francisco mandate effects separately from minimum wage changes. Although they are not reported in this paper, our results are nearly identical without including the minimum wage controls. ${ }^{4}$

Data on restaurant surcharges due to the Health Care Security Ordinance in San Francisco were collected by the authors in early 2009 and early 2010 (details below). In addition, the authors fielded the 2008 and 2009 Bay Area Employer Health Benefits Survey (details in Colla, Dow, and Dube 2011). Some calculations describing San Francisco employers are based on these data.

\subsection{Empirical Strategy}

The Health Care Security Ordinance offers a quasi-experimental design with distinct control groups: counties in the periphery areas outside San Francisco, and other U.S. MSAs of a significant size. Our identification strategy uses the San Francisco policy change as the exogenous variation, and considers covered firms that are economically affected as the "treatment group." We draw control groups from the counties surrounding San Francisco (Alameda, Contra Costa, Marin, and San Mateo) and counties from the other 24 largest MSAs in the United States. Our main identification strategy uses a spatial discontinuity approach: we compare San Francisco County to adjacent "periphery" counties within the broader San Francisco MSA. However, we go beyond a simple discontinuity framework by allowing for the possibility that "center" and "periphery" counties within MSAs have experienced differential trends. For this reason, we incorporate "center" and "periphery" counties within the 24 largest MSAs in the U.S. as additional controls. This approach is similar to previous work of comparing contiguous counties to assess minimum wage mandates (Dube, Lester and Reich 2010).

\footnotetext{
${ }^{4}$ Based on previous work that found no effect of minimum wages on employment using contiguous counties (Dube, Lester and Reich 2010, Dube, Naidu and Reich 2007), we do not expect a large bias due to these changes. The reduction in labor costs (between San Francisco and periphery) due to a reduced minimum wage gap is of a much smaller magnitude than the mandated increase in health expenditures. The minimum wage rose by $6.6 \%$ in San Francisco between 2006-2007 and 2008-2009 periods. During the same time, it rose by $12.3 \%$ in the peripheryrepresenting a 5.6\% reduction in the relative minimum wage in San Francisco. Let us consider restaurants as a particularly high-minimum wage sector, and take the largest estimate for the average earnings elasticity of minimum wage in restaurants from Dube, Lester and Reich (2010), 0.23 . This suggests a roughly $1.3 \%$ relative reduction in average earnings among San Francisco restaurants from minimum wage policies. However, the additional mandated expenditure due to the health mandate represents around $4.3 \%$ of the average restaurant wage in San Franciscosuggesting a much larger impact on labor costs than from the minimum wage changes.
} 
We begin with plotting the ratio of the outcomes between San Francisco and periphery counties, as well as the average ratio between centers and peripheries in other MSAs (weighted by MSA population) by quarter over the 2002-2010 period. We then consider trends in mean outcomes, simple difference-in-differences of mean outcomes, and a regression specification with additional controls. In all cases, we show the evidence for employment and average wages - for the overall private sector, as well as for specific high impact sectors. We calculate a difference-in-differences estimate for log employment or log earnings using quarterly data between 2002 and the first quarter of 2010.

$$
\delta_{1}=\left(\bar{Y}_{1, c, p o s t}-\bar{Y}_{1, p, p o s t}\right)-\left(\bar{Y}_{1, c, p r e}-\bar{Y}_{1, p, p r e}\right)
$$

Mean outcome $\bar{Y}_{m, l, t}$ is indexed by MSA $m$, where $m=1$ is San Francisco MSA; location $l$ which takes on $c$ ("center") or $p$ ("periphery); and time $t$, which takes on pre or post. So $\delta_{l}$ compares changes over time in San Francisco versus adjacent counties. Subtracting the average change in the Bay Area counties from the average change in San Francisco County removes biases in second period comparisons between the two groups that could be the result from permanent differences or shared trends.

We also calculate a "triple difference" estimate — which further nets out differential growth between center and periphery counties in other MSAs.

$$
\begin{aligned}
& \delta_{2}=\left[\left(\bar{Y}_{1, c, p o s t}-\bar{Y}_{1, p, p o s t}\right)-\left(\bar{Y}_{1, c, p r e}-\bar{Y}_{1, p, p r e}\right)\right]- \\
& \sum_{m=2}^{24} \omega_{m}\left[\left(\bar{Y}_{m, c, p o s t}-\bar{Y}_{m, p, p o s t}\right)-\left(\bar{Y}_{m, c, p r e}-\bar{Y}_{m, p, p r e}\right)\right]
\end{aligned}
$$

The additional term represents the mean employment trends in center versus peripheries in major MSAs generally over this period, weighted by population. Here, $\omega_{m}$ represents MSA $m$ 's share of the total population in the 24 MSAs.

Our regression specifications use a similar identification strategy by spatially differencing all variables, so that for all variables $Z$, define:

$$
Z_{m t}^{\Delta}=Z_{m c t}-\bar{Z}_{m p t}
$$


The superscript $\Delta$ denotes spatial differencing between the center and periphery outcomes. As above, periphery outcomes $\bar{Z}_{m p t}$ are constructed as population weighted means across periphery counties in MSA $m$. The regression is specified as:

$$
Y_{m t}^{\Delta}=\alpha d_{m t}+X_{m t}^{\Delta} \beta+\mu_{m}+\tau_{t}+\varepsilon_{m t}
$$

The treatment variable $d_{m t}$ takes on unity when $m=1$ (i.e., the MSA is San Francisco) and $t \in$ post,$\mu_{m}$ is a MSA fixed effect, and $\tau_{t}$ is a time fixed effect. The spatial differencing, along with the MSA and time fixed effect sweeps out variation across MSAs, and uses only the local differences to identify the policy effect; secondarily, it accounts for arbitrary center-periphery trends over this period by using the other 24 MSAs.

Our vector of controls $X$ represents spatially differenced values of the underlying county level controls as described above. The set of controls always includes log of annual county-level population, log of minimum wage measured quarterly at the county-level, and housing variables that are measured quarterly at the county-level. Housing variables include housing sales, housing prices, and 1-year lagged sales and prices. We also always include MSA-specific quarter dummies to account for seasonality. In our most saturated specification, we also include MSAspecific linear trends to account for additional long-term trend differences that may not be captured by other fixed effects and controls.

We estimate equation 3 separately for each industry, for alternative pre-periods (2002 to 2007, and 2006 to 2007), and with and without MSA-specific linear trends. After differencing center counties from periphery counties, our model has 825 quarter-MSA observations per industry sector. In addition, we estimate a time series version of equation 3 , where we use only within-San Francisco Bay Area variation:

$$
Y_{1 t}^{\Delta}=\alpha d_{1 t}+X_{1 t}^{\Delta \prime} \beta+\mu_{1}+\varepsilon_{m t}
$$

We estimate equation (3) using OLS and report standard errors clustered by MSA. For equation (4) we report Newey-West standard errors.

In addition to reporting traditional cluster-robust standard errors, we also report confidence intervals using Conley and Taber (2011), henceforth CT. This methodology was 
developed for circumstances where only a small number of policy changes are observed in the data and standard large-sample approximations used for inference may not be appropriate. This approach to inference uses asymptotic approximations that let the number of control units grow large, while the number of treated units remains small. As CT show, when the number of treated units is small (in our case it is one), the OLS estimate is inconsistent even with an unboundedly large number of untreated units. Moreover, inference using the cluster-robust standard errors can be misleading even if the number of clusters is large. The CT method is related to other recent papers that use a randomization or permutation type inference approach (e.g., Buchmueller, Dinardo and Valetta 2009; Abadie, Diamond, and Hainmueller 2007).

For a given variable $Z_{m t}$, define $\tilde{Z}_{m t}$ after partialing out time and MSA fixed effects:

$$
\begin{aligned}
& \bar{Z}_{m}=\frac{1}{T} \sum_{t=1}^{T} Z_{m t} \\
& \bar{Z}_{t}=\frac{1}{M} \sum_{m=1}^{M} Z_{m t} \\
& \bar{Z}=\frac{1}{M T} \sum_{t=1}^{T} \sum_{m=1}^{M} Z_{m t} \\
& \tilde{Z}_{m t}=Z_{m t}-\bar{Z}_{m}-\bar{Z}_{t}+\bar{Z}
\end{aligned}
$$

Here $M$ is the total number of MSAs, and $T$ is the number of quarters in our sample. Then, we can define the CT estimator for the distribution of $\alpha$ from equation (3) as follows:

$$
\hat{\Gamma}(a)=\frac{1}{M} \sum_{m=2}^{M} 1\left(\frac{\Sigma_{t=1}^{T}\left(d_{1 t}-\bar{d}_{1}\right)\left(\tilde{Y}_{m t}^{\Delta}-\tilde{X}_{m t}^{\Delta} \widehat{\beta}^{\prime}\right.}{\Sigma_{t=1}^{T}\left(d_{1 t}-\bar{d}_{1}\right)^{2}}\right)
$$

The key idea behind the CT estimator is that information from other MSAs may be used to consistently estimate the distribution of the treatment effect. In our case, since we want to use local comparisons, we first spatially difference all variables, and then use the CT estimator on these data. We partial out time and MSA fixed effects as indicated by the tilde above the variable name. We then regress the residuals from this on a center county interaction with the post-period (2008-2010) for each MSA as indicated in equation (5). Using these 24 point estimates of the treatment effects, we create a $92 \%$ confidence interval for the treatment coefficient in San Francisco (given the total of $25 \mathrm{MSAs}$, this is the highest confidence level we can report). Intuitively, the spatial-differenced version of the CT estimator allows us to answer the following question: just by chance alone, what are the odds that San Francisco would have seen a certain 
change in outcome as compared to its neighbors? We can answer this question by comparing the other 24 MSAs center and periphery counties, and using this information to form confidence bounds around the San Francisco effect. For all specifications with 25 MSAs, we report the CT bounds along with the OLS estimate and clustered standard errors.

\section{Findings}

\subsection{Descriptive Trends}

Table 2 provides descriptive statistics over the study period for our outcome and control variables in San Francisco, Bay Area periphery counties, control MSA center counties, and control MSA periphery counties. San Francisco County is smaller than comparison counties, with a higher minimum wage, higher housing prices, and higher wages across study industries. A larger portion of private industry is composed of accommodation and food services, including restaurants, than comparison counties, while retail makes up a smaller portion of private employment.

Figure 1 provides the first set of evidence on the impact of the Health Care Security Ordinance on employment and earnings trends in San Francisco, displaying weighted averages of Bay Area periphery counties (our primary control group), the 24 other largest MSA center counties, and periphery counties of the other 24 MSAs (our additional control groups). We calculate the simple ratio of outcomes in the center county versus the periphery counties for San Francisco and the other MSAs in the 2002 to 2010 period and normalize to Q4 2007, the last

period before treatment. For the most part, Figure 1 displays similar trends in San Francisco and periphery Bay Area counties over the pre-period, especially so in highly impacted sectors.

Moreover, there does not seem to be much of a trend on average between center and periphery counties in the other 24 MSAs. These two results provide additional support for our research design. When we consider changes after the implementation of the policy (i.e., after 2007), we find no visual indication of employment or earnings decline after 2007. (Appendix II shows these trends during the entire data period available from 1990 to 2010.)

Table 3 builds on the graphical evidence in Figure 1 by calculating the unconditional double and triple difference estimates. We report the employment and earnings trends in San 
Francisco, periphery Bay Area counties, center counties in the other 24 MSAs, and periphery counties in other MSAs using seasonally adjusted data. The first two rows report the average logged earnings and employment in each of these four groups in the Pre and Post periods. The third row reports the simple difference between the Pre and Post amounts; since those are logs, we can interpret the resulting difference in percentage terms. The fourth row reports the "difference-in-difference" between center and periphery-both for the San Francisco Bay Area as well as for the other 24 MSAs; finally, the fifth row calculates the "triple difference" by subtracting the latter from the former. For example, overall private sector employment in San Francisco was 3.4\% higher between January of 2008 and March of 2010 (Post) compared with 2002 to 2007 (Pre), while employment in the SF neighboring counties (Alameda, Contra Costa, Marin, San Mateo) shrank by 3.0\% compared to the pre-period (Table 3).

In other MSA counties, employment patterns were slightly negative over this time period. Neither the double difference (6.5\%) nor the triple difference (7.2\%) suggests employment loss. Indeed, for all four industry groupings, the simple double and triple difference estimates are either small (at most a $0.5 \%$ reduction) or positive, pointing away from employment or wage loss. Although not shown in the table, all these estimates are all indistinguishable from zero at the $90 \%$ level.

\subsection{Regression Results}

Table $4 \mathrm{a}$ reports the estimated treatment effect (and CT confidence intervals where relevant) for $\log$ employment in the four industry groups; Table $4 \mathrm{~b}$ reports analogous results for log of average earnings. The first four columns are for the San Francisco MSA only, as specified in equation (4). The last four columns are for the $25 \mathrm{MSA}$ sample, with the regressions specified by equation (3) with the CT bounds specified in equation (5). The specifications also vary by preperiod (beginning in 2002 or 2006) and whether or not an MSA-specific linear time trend is included. Although we report the Newey-West (columns 1-4) and cluster-robust (columns 5-8) standard errors for comparison, we put more weight on the CT bounds for statistical inference. Moreover, we refer to column 8 as our preferred specification, due to its having the richest set of controls and most immediate pre-period. In the presence of time-varying heterogeneity in county employment, inclusion of a longer pre-period may be problematic. Because of this we are concerned that the estimates based on data going back to 2002 may be more sensitive to mis- 
specifications, thus we prefer the specifications comparing back only to 2006. This preference is further supported by the falsification results in Table 5 discussed below, which reveal several spurious effects in the models comparing to 2002, whereas the models with trends comparing only to 2006 appropriately pass those falsification tests. Moreover, as noted below, specifications with linear trends tend to be less noisy than those without.

As shown in Table 4a, after controlling for (spatially differenced) log of population, $\log$ of minimum wage, housing controls, time, MSA, and seasonal fixed effects, we did not find evidence of a negative employment effect in the four industry groups. Indeed, many of the significant employment effects were positive in sign, though they varied in magnitude and precision. For the San Francisco MSA only sample, the estimates ranged between -0.035 and 0.063 . For the all MSA sample, the point estimates for employment ranged from -0.024 to 0.065 . The $\mathrm{CT}$ lower bound across all specifications was -0.040 . For our preferred specification 8 , all the point estimates - including high impact sectors - were close to zero, and the negative lower bounds were always less than $1 \%$.

We note that in general, when a linear trend is not included, the CT confidence intervals are much wider than those based on conventional standard errors. The $\mathrm{CT}$ intervals were much smaller (and comparable to conventional ones) when we include an MSA specific linear trend, which is unsurprising given the variation in center-periphery trends across various MSAs.

When we turn to average earnings (Table $4 \mathrm{~b}$ ), the range of coefficients in the San Francisco MSA only sample ranged somewhat widely between -0.074 and 0.082 . However, once we account for center-periphery trends using other MSAs, the range narrows to -0.027 to 0.050 . The CT lower bounds are no smaller than -0.041 , while for our preferred specification 8 , earnings reductions are bounded below at -0.008 across sectors.

To show the data more clearly, Figure 2 displays the San Francisco coefficients from specification 8 for the post-mandate period compared to the parallel coefficients estimated for each of the other 25 MSAs that are obtained as part of the Conley-Taber estimate of $\hat{\Gamma}(a)$. All coefficients are ranked in an ascending order for each bar graph. Loosely speaking, the coefficient for a given MSA shows the change in center-periphery differential after 2007 in that MSA conditional on other controls. For the other 24 MSAs, the coefficient can be thought of as 
the measured effects of "placebo" laws in those MSAs that happened during the same time as in San Francisco. If San Francisco employment or earnings were adversely affected by the 2008 Ordinance then San Francisco should lie on the left part of the bar graph, since none of the other MSAs actually enacted a policy. Instead, they are always above the median in terms of employment. For earnings, they are either the in lower-middle or upper part of the distribution. Therefore, Figure 2 provides graphical evidence of a lack of employment and earnings effects from the San Francisco Ordinance.

Overall, our results provide evidence that over the first 27 months of the enactment of the policy, there has not been any discernable reduction in employment or earnings in San Francisco. The majority of our regression estimates are positive in sign for both outcomes, as are the majority of the simple (unconditional) double or triple-difference estimates. These quantitative results are reinforced by the plots of employment and earnings differences between San Francisco and neighbors. Using conventional standard errors and other MSAs as controls we observe no significant negative effects in highly impacted sectors. For some of our specifications the Conley-Taber confidence intervals are much wider than those based on cluster-robust standard errors. For our preferred specification, Conley-Taber confidence intervals rule out losses of employment or earnings reductions of greater than $1 \%$ for both overall private sector, as well as specific high-impact sectors that we consider. Across all the specifications we considerincluding short versus long pre-period, and with and without MSA specific linear trends - the CT bounds rule out earnings or employment reductions greater than $4.1 \%$.

\subsection{Robustness Tests}

We conducted a falsification exercise designed to provide additional information about the validity of our research design generally as well as for particular specifications. In particular, we change the definition of "treatment" from 2008-2010 to only the year 2007-the last year prior to the actual intervention; for all other years the treatment is coded as zero. Also, for all non-San Francisco MSAs, the treatment continues to be coded as zero.

What should we expect from this exercise? If the regression is specified correctly, and the null hypothesis is maintained, then the coefficient should be zero. However, if the true effect is negative but there is a positive and spurious "pre-trend," then the coefficient should be positive. Conversely, if the true effect is negative, but there is an unusually low value in 2007 , then the 
measured effect should be negative. There are other possibilities, but these three are the most relevant ones given our measured effects close to zero in Tables $4 \mathrm{a}$ and $4 \mathrm{~b}$. We perform this exercise for all the four all-MSA specifications and for the same industries.

Table 5 shows several patterns. First, we note that none of the employment coefficients are statistically significant based on the CT confidence bounds. This is very reassuring for our research design. Moreover, the point estimates for our preferred specification (the fourth column here, column 8 in Table 4) are very close to zero, which again provides additional validation for our choice.

Second, for earnings, 6 of the 16 specifications are significant using the CT bounds at the $92 \%$ level. All six of these coefficients are for all private and retail, suggesting specification errors may be a concern. Reassuringly, however, for the preferred specification 8 , none of the coefficients are statistically significant_-including retail and all private — and the point estimates are generally small in magnitude.

In addition, we performed a number of further tests (not shown in tables) to check the robustness of our results to various changes in specification. After viewing the plots of employment and earnings in Figure 1 and Appendix II, we looked into the dip in the ratio of San Francisco County earnings to surrounding Bay Area counties in quarter 1 of 2009. After examining the data more carefully and speaking with the Bureau of Labor Statistics, we identified this dip to be the result of a large spike in weekly earnings in San Mateo County in the manufacturing sector. We attribute this spike to the buyout of Genentech Inc. by the Roche Group (Genentech 2009). We changed our outlier threshold to be 2.5 standard deviations from the mean, imputing this observation and found no difference in our results (the coefficient on all private earnings in specification 8 changes from -0.003 to 0.008 , both insignificant). We also dropped this observation from analysis and saw no change in results, indicating that our results are not particularly sensitive to extreme circumstances in a single county or time period.

Additionally, we estimated regressions including Santa Clara County (another county neighboring San Francisco, but which is classified as San Jose CBSA, the $29^{\text {th }}$ largest CBSA in the U.S.) as a control, and the results were for the most part similar in magnitude and direction 
(results not shown). The negative earnings effects for all private and retail industries in some specifications changed to insignificant or positive.

A possible threat to the validity of our research design is the beginning of the 2008-2009 recession during the implementation of the Health Care Security Ordinance. If San Francisco tended to weather a recession better than control counties, and this relationship differed from center-periphery recession effects in other MSAs, it would cause us to estimate a spuriously small disemployment effect of the Ordinance. However, an examination of the figures in Appendix II shows that in the 1990-1991 and 2001 recessions, San Francisco County had big relative drop in employment compared to its neighbors, casting doubt on this alternative explanation.

\subsection{Evidence from Product Markets}

When firms competing locally are all subject to the same mandate, they can also pass on some of the costs to consumers via increased output product prices, as discussed in Section 2. This is particularly the case for restaurants, who primarily serve a local market, and in this case all restaurants in San Francisco with 20 or more employees received the same input price shock so we might expect to see some rise in output prices. (Approximately a quarter of eating and drinking establishments in San Francisco have 20 or more employees and 68\% of workers in San Francisco restaurants work in restaurants with 20 or more employees, based on our calculations from Dun and Bradstreet and American Community Survey data). Indeed, there is widespread anecdotal evidence that some San Francisco establishments have instituted a specific surcharge to help defray the added costs of the mandate.

To assess the extent of restaurant price surcharges we interviewed a sample of restaurants by telephone in 2009 and 2010 to quantify the prevalence and magnitude of health-specific surcharges. Our sample of 340 restaurants was drawn randomly from a Dun and Bradstreet database provided by Survey Sampling Incorporated in 2007, consisting of establishments in San Francisco with 20 or more employees, and classified as "Eating and Drinking Places." Of the 340 restaurants which we attempted to contact, we successfully interviewed 217 (64\%) at least 
once. ${ }^{5}$ We found that $25 \%$ of restaurants in our completed 2009 sample (standard error of $3.7 \%$ ) and $27 \%$ of restaurants in our completed 2010 sample (standard error of $4.2 \%$ ) had instituted a surcharge on their bills specifically attributed to health benefit costs (these results are not displayed in the tables). Although the extent and form of the surcharge varied, most firms reported a charge of $4 \%$ on the bill, which was the mean, median and the mode for firms using proportional charges in 2009 (the majority). Larger firms were more likely to institute a surcharge. This could reflect imperfect substitutability between products by firm size; smaller firms subject to the mandate are less likely to have products that are differentiated from exempt restaurants (with fewer than 20 employees). As a result, smaller restaurants that are subject to the mandate are less likely to be able to pass the cost onto consumers.

We investigated the surcharges because they are the most easily measured form of passthrough to consumers. Firms that did not impose a line item surcharge may have still adjusted their menu prices upwards; we have not investigated this type of response. We have, however, been able to use data from the 2008 Bay Area Employer Health Benefits Survey to calculate that $68 \%$ of the restaurants who have instituted these surcharges already offered health benefits in 2007, prior to the implementation of the Health Care Security Ordinance. Thus it could be that some firms who wanted to increase prices for other reasons did so as a surcharge under the guise of the health mandate, believing that demand elasticity responses to health-linked surcharges might be smaller than unexplained menu price increases. However, Colla, Dow, and Dube (2011) have calculated that even among firms offering health insurance at baseline, most were required to expand health spending to meet the mandated spending levels, thus it is not surprising that many restaurants opted to raise product prices.

\subsection{Who Bears the Cost of the Mandate?}

\footnotetext{
${ }^{5}$ We interviewed 142 restaurants in 2009 and 162 in 2010, including 89 interviewed twice in successive years. Firms who did not respond in either year did not differ significantly from responders by either number of employees or restaurant type (full service, food stand, fast food, lunchroom/cafeteria, caterer, bar/club). Among firms who were interviewed in 2009 that we attempted to re-contact in 2010, non-responders in 2010 (25\% of whom reported surcharges in 2009) did not differ from those interviewed again in 2010 (26\% of whom had reported surcharges in 2009). Thus although the overall response rate is somewhat low, there is no evidence that non-response is systematic. Among restaurants interviewed in both years, 85\% had concordant surcharge reports across the two surveys, suggesting high stability.
} 
In this section we assess the magnitude of estimated earnings and consumer price increases relative to the estimated spending increase ("gap") necessary for firms to come into compliance. Regarding earnings, we first note that the QCEW data consist of employment and earnings across all firms, including small firms not subject to the mandate, thus reported effects in Table $4 \mathrm{~b}$ are averages across all firm sizes. For example, according to County Business Patterns data (Table 1), 68\% of restaurant workers are in firms with more than 20 employees. Given these parameters and the magnitude of changes necessary in these high impact sectors described above (on average restaurants need to increase health spending by $\$ 0.62$ per worker hour, accommodation and food services by $\$ 0.57$ and retail by $\$ 0.41$ per worker hour), we can rule out complete pass-through of these benefit increases to earnings in these high impact sectors. For example, our preferred estimate (Table $4 \mathrm{~b}$ column 8 ) suggests a $0.4 \%$ earnings drop among restaurant workers. This would account for just $\$ 0.05$ per hour (using mean restaurant wage of $\$ 13.34$ in Table 1), and even when attributing the entire drop to the $68 \%$ of restaurant workers in firms of size 20 and above, this would pay for just $\$ 0.08$ of the $\$ 0.62$ gap, or $12 \%$ pass-through. (Based on the lower bound of the confidence interval of the earnings effect in this preferred specification, we can statistically rule out more than a $26 \%$ earnings pass-through in restaurants.) The comparable figures for the retail industry and accommodation and food services industry are both positive, indicating no pass-through. When considering the private sector overall, the gap is lower ( $\$ 0.29$ per hour) and the corresponding pass-through is $\$ 0.11$ per hour (38\% of the gap) at our preferred point estimate (though at the lower bound of our $92 \%$ confidence interval we cannot rule out $100 \%$ pass-through).

The lower earnings pass-through in the restaurant industry likely reflects both the greater difficulty in lowering wages in an industry with a large proportion of minimum wage workers, but also the greater ability of firms in this sector to pass on costs to consumers. As discussed in the previous section, the evidence suggests at least some of the cost of the mandate is absorbed as higher costs to consumers. The precise extent of pass-through to consumers depends on the joint distribution of surcharges and restaurant revenue per worker, which we do not fully know, but we can approximate the order of magnitude. According to the Economic Census in 2007, in San Francisco, the total sales for restaurants were $\$ 2.85$ billion, while there were 46,873 workers, indicating that the annual sales/worker was around $\$ 60,780$. If we divide this by 1,924 hours per year and multiply by $4 \%$, we calculate surcharge revenue of approximately $\$ 1.26$ per 
hour. $^{6}$ This is almost exactly the 2008 mandated spending amount of $\$ 1.17$ per hour for firms with 20-99 employees (but lower than the $\$ 1.76$ mandate for firms with 100 or more employees), indicating that the average restaurant could fully fund health benefits with this surcharge. To calculate overall pass-through, we must take into account that only $25 \%$ of restaurants reported surcharges, yielding an estimate that surcharges could account for $\$ 0.32$ of the $\$ 0.62$ spending gap reported in Table 1 for the restaurant sector as a whole. This would represent a pass-through to prices of $51 \%$ of the gap. This is likely an underestimate, however, since surcharges are more common in full service restaurants (and it ignores menu prices increases not labeled as surcharges), suggesting substantial pass-through of costs to consumers at least in this one local service industry.

Each employer's behavior in passing through costs to employees and consumers will vary depending on the extent of that firm's gap, as well as elasticities of labor supply by their workers and demand elasticities for their products and services. Just as consumer pass-through is reported by only $25 \%$ of firms, it may be that labor market effects are concentrated in a small subset of firms as well. To further quantify the proportion of employers making earnings and employment adjustments, Table 6 presents self-reported behavioral responses by San Francisco for-profit firms in the 2009 Bay Area Employer Health Benefits Survey who had 20 or more employees and thus were subject to the mandate. Firms reporting wage pass-through (reduced pay raises or bonuses) account for a relatively small proportion of workers subject to the mandate (6\%), which is consistent with the QCEW findings of relatively small pass-through. Interestingly though, firms report paying for the expanded health spending in part by reducing spending for other nonmandated benefits (including dependent health care) for 14\% of workers, which would not be captured in the QCEW earnings data.

Table 6 also indicates that firms who reported that complying with the spending mandate had some negative employment implications (reduced hours and/or number of employees) employed $11 \%$ of workers. Such data must be interpreted cautiously, as it would be quite difficult for employers to distinguish the effects of the spending mandate separately from other labor market forces, including the deepening recession occurring simultaneously. It is also possible that respondents' own political views could have led to systematic mis-reporting.

\footnotetext{
${ }^{6}$ In 2007, according to the ACS, the average usual weekly hours for restaurant workers in San Francisco was 37.
} 
Furthermore, the survey did not capture the magnitude of employment effects within each firm, nor did it capture general equilibrium effects that could have occurred if some firms expanded employment to compensate for shrinking by other firms. Nevertheless, the proportion of firms subject to the mandate who reported negative employment effects represented a relatively small number of workers, and provides further evidence consistent with our QCEW estimates that any negative employment effects were minor overall.

\section{Discussion and Conclusion}

Although we should be cautious about inference from a single policy change, the evidence thus far suggests that San Francisco employers did not decrease employment or wages appreciably in response to the health benefit mandate in the first few years of implementation. Adding information from a larger number of control cases in the QCEW analysis allows for more robust inference, and indeed rules out all but small negative effects. Under our preferred specification, we can rule out reductions in earnings and employment of more than $1 \%$ across all subsectors we consider. When we consider a longer pre-period, we find negative employment effects up to $2.4 \%$ in the accommodation and food services industry (though not in all private employment), and a $3 \%$ drop in all private earnings.

At our preferred point estimates, tour findings indicate a $\$ 0.11$ per hour earnings decrease in the private sector overall among firms subject to the mandate, which is about $38 \%$ of the required health spending increase. In the restaurant sector the pass-through lowered earnings by an estimated $\$ 0.08$, which represents just $12 \%$ pass-through, but we estimate another $51 \%$ of restaurant costs were passed through to consumers in the form of health-specific menu surcharges. Additional pass-through to total compensation occurred in the form of reductions in other non-mandated benefits, and further consumer pass-through may also have occurred in the form of non-specific price increases, but we are not able to quantify their magnitudes.

While this evidence conflicts with some earlier research indicating that the full incidence of benefit mandates was shifted to wages (Gruber 1994), these findings are consistent with a recent study of Hawaii's pay-or-play mandate, which also did not find negative effects on overall employment (Buchmueller et al. 2009). However, Hawaiian employers may have substituted toward part-time workers (under 20 hours per week) who were not covered by the insurance 
mandate, which is an unlikely behavioral response in San Francisco where workers with 8 or more hours per week are covered by the mandate. Given that average weekly earnings in San Francisco were estimated to be largely unaffected by the mandate, it appears that firms were not reducing the number of hours worked per employee as a response to the mandate. The lack of employment effects is also consistent with the literature suggesting that employer cost increases due to related minimum wage increases often do not have detectable negative employment effects. In fact, San Francisco's institution of a city-wide minimum wage in 2005 similarly had no appreciable impact on employment growth in affected sectors (Dube, Naidu and Reich 2007).

Given the apparently incomplete pass-through of costs to employee wages, further research on output product price effects would be particularly helpful. It also remains to be seen whether the restaurant surcharges we observed will be a lasting feature in San Francisco, or whether the surcharge will simply be folded into menu prices. The latter is more likely if the surcharge reflects costs of adjusting nominal prices sharply due to rigidities. At the same time, if restaurants are utilizing surcharges because they are less salient than menu price increases, then this might be an enduring feature of restaurant pricing in the city. For example, Chetty, Looney and Kroft (2009) show that shoppers in the supermarket largely ignore sales taxes in making purchasing decisions. Since a surcharge may appear as a form of tax (as opposed to a higher menu price), it could have reduced the impact on consumer behavior. However, if inattention declines over time as consumers learn, the efficacy of the strategy will diminish. Finally, at least some restaurants have publicized the surcharge as allowing them to provide health care to their employees. If consumers are willing to pay somewhat more for "fairness" reasons (like purchasing "fair-trade" coffee, or "no sweat" apparel), this could also explain why some restaurants have adopted a surcharge. Either way, we interpret the evidence to suggest that some firms partly reacted to the health mandate by passing on costs to consumers. Future research could analyze menu prices using our longitudinal spatial discontinuity approach.

While such price increases may be possible in service industries that only compete locally such as restaurants, other San Francisco firms competing with firms in markets elsewhere may not have latitude for such price increases. Indeed, the health-specific surcharges in San Francisco appear to be largely contained to the restaurant industry, as only $2 \%$ of other firms report them in the 2009 Bay Area Employer Health Benefits Survey. In the long run, with the 
exception of minimum wage workers, neoclassical economic theory predicts that the costs of expanded benefits will be eventually passed on to workers in the form of smaller wage increases. This will be of interest to continue to evaluate over a longer time horizon, to the extent possible.

Healthy San Francisco has succeeded in providing health services to nearly all previously uninsured residents in the first four years of implementation (San Francisco Department of Public Health 2010), ${ }^{7}$ in part by collecting fees (totaling \$34 million in fiscal year 2009-10) from employers using the "pay" option under the employer mandate (Healthy San Francisco Program Statistics 2011). Little is known still about the extent to which these enrollees were drawn from the uninsured versus crowded out of private plans (enrollees must have been uninsured for 90 days to become eligible), but it is likely that the number of uninsured in San Francisco without access to affordable health care has been substantially reduced in the first four years of Healthy San Francisco implementation. Colla, Dow, and Dube (2011) found no evidence of crowd-out from firms dropping insurance offering in the first year following implementation, based on data from the 2008 Bay Area Employer Health Benefits Survey.

This evidence indicates that together with private benefit expansions, San Francisco is closer to achieving universal access to health care than it was prior to 2008 . While neoclassical theory indicates that in the long run workers pay for these additional benefits either through real wage reductions or lay-offs for low-wage workers, these effects have been muted in San Francisco in the first two years into implementation of the employer health spending mandate. San Francisco has many unique characteristics that make conclusions difficult to generalize (for example geographic location and demographic makeup of population), but thus far the Health Care Security Ordinance has expanded coverage with little negative impact on the labor market.

\section{References}

Anderson, D. (2006). “Economics by Example.” MacMillan p. 29.

Brown, C. (1999). "Minimum Wages, Employment, and the Distribution of Income." Handbook of Labor Economics, Volume 3, Elsevier Science.

\footnotetext{
${ }^{7}$ Estimates prior to the introduction of Healthy San Francisco indicated that about 60,000 San Francisco residents were uninsured in 2007 and Healthy San Francisco has enrolled 54,312 residents to date (Healthy San Francisco Program Statistics 2011, San Francisco Department of Public Health 2010).
} 
Brown, D. (1990). “The Restaurant and Fast Food Race: Who's Winning?” Southern Economic Journal, 56(4):984-995.

Buchmueller, T.C., DiNardo, J., and R.G. Valletta (2009). "The Effect of an Employer Health Insurance Mandate on Health Insurance Coverage and the Demand for Labor: Evidence from Hawaii.” FRBSF Working Paper.

California Department of Finance, E-4 Population Estimates for Cities, Counties, and the State. http://www.dof.ca.gov/research/demographic/reports/estimates/e-4/19912000/documents/E-4_90-00_Rpt.XLS and

http://www.dof.ca.gov/research/demographic/reports/estimates/e-4/2001-09/. Accessed January 11, 2010.

Card, D. and A.B. Krueger (1994). "Minimum Wages and Employment: A Case Study of the Fast-Food Industry in New Jersey and Pennsylvania." The American Economic Review, 84(4):772-93.

Card, D. and A.B. Krueger (2000). "Minimum Wages and Employment: A Case Study of the Fast-Food Industry in New Jersey and Pennsylvania: Reply." The American Economic Review, 90(5):1397-1420.

Chetty, R., Looney, A., and K. Kroft (2009). "Salience and Taxation: Theory and Evidence." American Economic Review, 99(4): 1145-77.

City and County of San Francisco (2011). "Analysis of the Health Care Security Ordinance: 2010 Annual Reporting Forms.” Office of Labor Standards Enforcement. June 6, 2011.

Colla, C.H., Dow, W.H., and A. Dube (2011). "How do employers react to a pay-or-play mandate? Early Evidence from San Francisco.” Forum for Health Economics \& Policy, 14(2), article 4.

Conley T.G. and C.R. Taber (2011). "Inference with "Difference in Differences" with a Small Number of Policy Changes." Review of Economics and Statistics, 93(1): 113-125.

County Business Patterns (U.S. Census). http://censtats.census.gov/cgi-bin/cbpnaic/cbpsect.pl. Accessed August 21, 2009.

Cutler, D.M. and B.C. Madrian (1998). "Labor Market Responses to Rising Health Insurance Costs: Evidence on Hours Worked," RAND Journal of Economics, The RAND Corporation, 29(3): 509-530.

Donald, S.G. and K. Lang (2007). "Inference with Difference-in-Differences and Other Panel Data." The Review of Economics and Statistics, 89(2): 221-233. 
Dube, A., Lester, T.W., and M. Reich (2010). "Minimum Wage Effects Across State Borders: Estimates Using Contiguous Counties." Review of Economics and Statistics, 92(4): 945964.

Dube, A., Naidu, S., and M. Reich (2007). "The Economic Effects of a Citywide Minimum Wage." Industrial and Labor Relations Review, 60(4): 522-543.

Frank, R.H. and B. Bernanke (2003). "Principles of Microeconomics." McGraw-Hill/Irwin, page 95.

Genentech Inc. "Roche Completes Acquisition of Genentech.” Thursday, Mar 26, 2009. http://www.gene.com/gene/news/press-releases/display.do?method=detail\&id=12007.

Gruber, J. (1994), “The Incidence of Mandated Maternity Benefits." American Economic Review, 84:622-41.

Gruber, J. and A.B. Krueger (1991). "The Incidence of Mandated Employer-Provided Health Insurance: Lessons from Workers' Compensation Insurance." In Tax Policy and the Economy, ed. D. Bradford, 111-44. Cambridge, Mass: MIT Press.

Healthy San Francisco. http://www.healthysanfrancisco.org/visitors/Who_Qualifies.aspx. Accessed August 21, 2009.

Healthy San Francisco. Annual Report to the San Francisco Health Commission. Fiscal year 2009-2010. http://www.healthysanfrancisco.org/files/PDF/2009-

10_HSF_Annual_Report.pdf

Healthy San Francisco Program Statistics.

http://www.healthysanfrancisco.org/files/Charts/index.html?DataDate=08082009\&PCou $\mathrm{nt}=45131$. Accessed June 24, 2011.

Kaestner, R. (1996). "The Effect of Government-Mandated Benefits on Youth Employment," Industrial and Labor Relations Review, 50(1): 122-142.

Kahn, S. (1997). "Evidence of Nominal Wage Stickiness from Microdata." The American Economic Review, 87(5): 993-1008.

Mandelbaum, R. (September 18, 2009). "Is the Employer Mandate a Job Killer? Not in San Francisco.” New York Times. http://boss.blogs.nytimes.com/2009/09/18/is-theemployer-mandate-a-job-killer-not-in-san-francisco/.

Monheit, A.C., Hagan, M.M., Berk, M.L., and P.J. Farley (1985). "The Employed Uninsured and the Role of Public Policy." Inquiry, 22(4): 348-64.

Pear, R. "Political Focus on Jobs in Health Fight." New York Times, January 16, 2011: A19. 
Reich, M. and A. Laitinen (2003). "Raising Low Pay in a High Income City: The Economics of a San Francisco Minimum Wage.” Working Paper No. 99, Institute of Industrial Relations, University of California, Berkeley.

Ruggles, S., Sobek, M., Alexander, T., Fitch, C.A., Goeken, R., Hall, P.K., King, M., and C. Ronnander (2008). Integrated Public Use Microdata Series: Version 4.0. Minneapolis, MN: Minnesota Population Center.

San Francisco Department of Public Health (July 2009). "Status Report on the Implementation of the San Francisco Health Care Security Ordinance.” Accessed August 21, 2009. http://www.healthysanfrancisco.org/files/PDF/July_2009_BoS_Report.pdf

San Francisco Department of Public Health (June 2010). "Status Report on the Implementation of the San Francisco Health Care Security Ordinance.” Accessed February 22, 2011. http://healthysanfrancisco.org/files/PDF/June_2010_BoS_Report.pdf.

San Francisco Office of Labor Standards Enforcement, Health Care Security Ordinance. http://www.sfgov.org/site/olse_index.asp?id=45168. Accessed August 21, 2009.

Summers, L.H. (1989). "Some Simple Economics of Mandated Benefits." The American Economic Review, 79(2): 177-183.

Thurston, N.K. (1997). "Labor Market Effects of Hawaii's Mandatory Employer-Provided Health Insurance.” Industrial and Labor Relations Review, 51(1): 117-135.

Viscusi, W.K., and M.J. Moore (1987). "Workers' Compensation: Wage Effects, Benefit Inadequacies, and the Value of Health Losses." Review of Economics and Statistics, 69(2): 249-61.

Yelowitz, A. (2004). "The Economic Impact of Proposition 72 on California Employers." Employment Policies Institute, September 2004. 


\section{FIGURE 1 \\ Ratio of Center County EMployment And WAges to Periphery Counties SAN Francisco County, SAN Francisco Periphery Counties, MSA CENTER Counties, MSA PERIPHERY COUNTIES: 2002-2010}

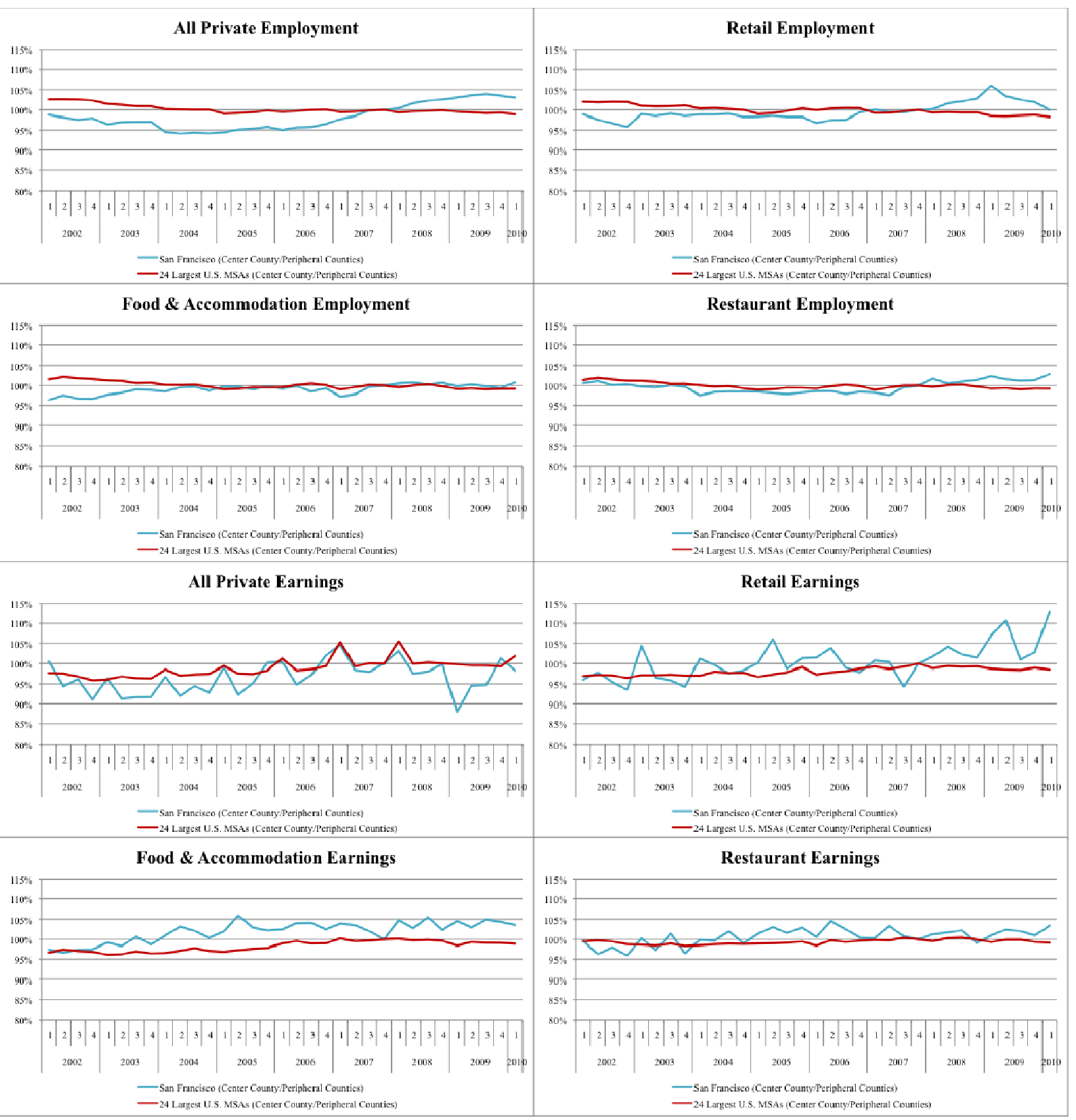

Notes. Figures are normalized to Q4 2007, the last period before treatment. Quarterly earnings and employment data from the Quarterly Census of Employment and Wages, Bureau of Labor Statistics. 
FIGURE 2

Coefficients on Center County Treatment Period Variables for ALl 25 MSAs: LOG OF EMPLOYMENT AND EARNINGS REGRESSIONS

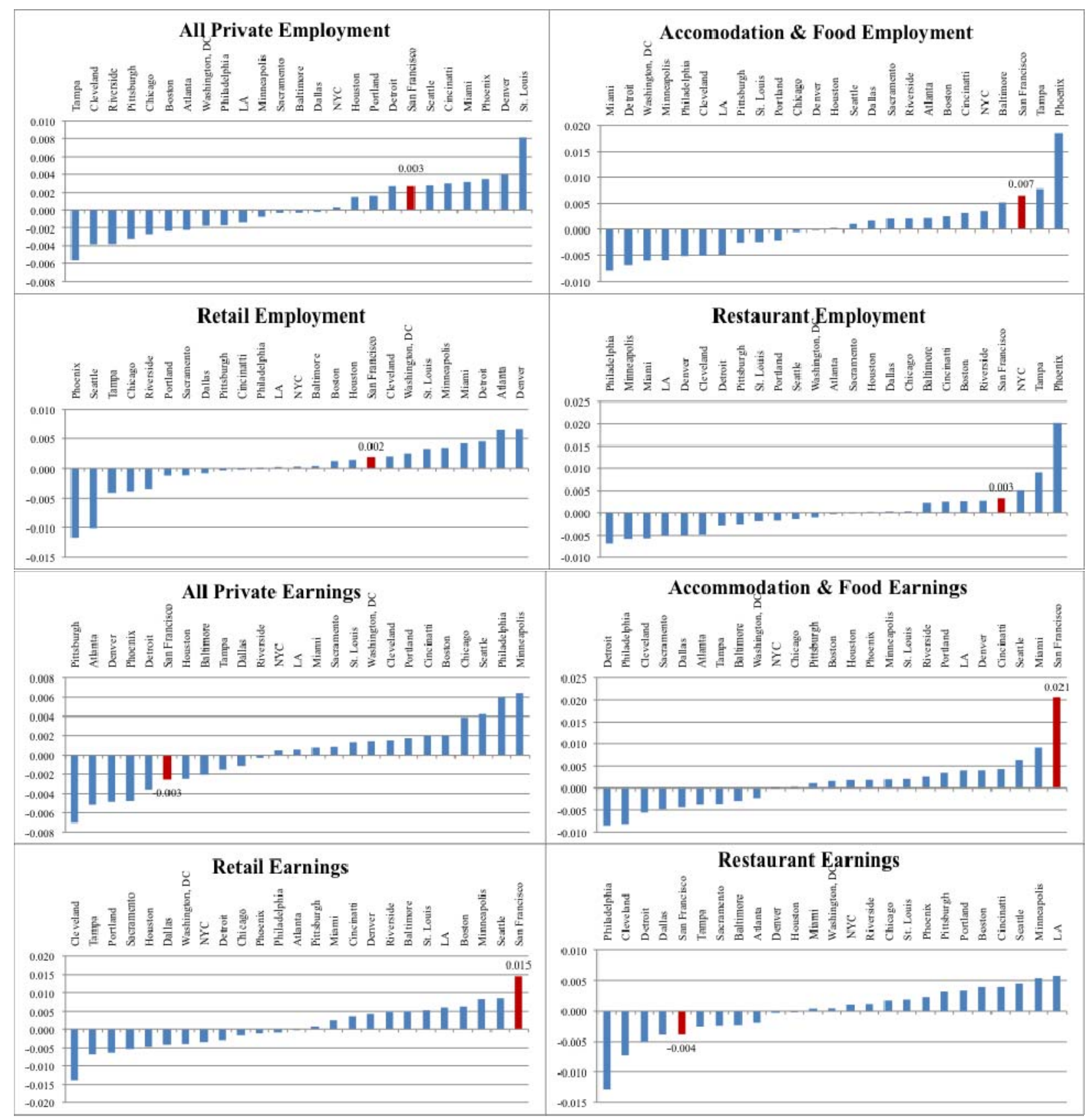

Notes. Bars indicate coefficients on the treatment period (2008-2010) in center counties in the 25 largest U.S. MSAs, compared to periphery counties using the Conley-Taber estimator. All outcomes and controls are spatially differenced (center minus periphery). The pre-period is 2006 to 2007 . These regressions adjust for county population, county minimum wage, housing controls, time fixed effects, a linear time trend and seasonal controls. 
TABLE 1

SAN FRANCISCO HOURLY WAGE AND GAP IN SPENDING BY INDUSTRY

\begin{tabular}{|c|c|c|c|c|}
\hline & $\begin{array}{l}\text { All Private } \\
\text { Industry }\end{array}$ & Retail & $\begin{array}{l}\text { Accommodation } \\
\text { and Food } \\
\text { Services }\end{array}$ & $\underline{\text { Restaurants }}$ \\
\hline Median Hourly Wage & $\$ 21.63$ & $\$ 16.83$ & $\$ 12.02$ & $\$ 11.08$ \\
\hline Mean Hourly Wage & $\$ 32.42$ & $\$ 23.38$ & $\$ 14.89$ & $\$ 13.34$ \\
\hline Proportion Earning $\leq \$ 10 /$ Hour & $17.59 \%$ & $26.02 \%$ & $39.06 \%$ & $45.11 \%$ \\
\hline $\begin{array}{l}\text { Gap in Baseline Health Benefit } \\
\text { Spending and Coverage }\end{array}$ & $\$ 0.29$ & $\$ 0.41$ & $\$ 0.57$ & $\$ 0.62$ \\
\hline Gap/Median Wage & $1.36 \%$ & $2.45 \%$ & $4.78 \%$ & $5.62 \%$ \\
\hline Gap/Mean Wage & $0.91 \%$ & $1.76 \%$ & $3.86 \%$ & $4.66 \%$ \\
\hline $\begin{array}{l}\text { Estimated Proportion of Employees in } \\
\text { Firms with } \geq 20 \text { Employees }\end{array}$ & $75.71 \%$ & $64.98 \%$ & $75.48 \%$ & $68.30 \%$ \\
\hline
\end{tabular}

Notes. Wage data are from the 2007 American Community Survey for all firm sizes (Ruggles et al. 2008). Gap data are from the 2008 Bay Area Employer Health Benefit Survey. Preliminary gap calculations are described in Colla, Dow, Dube 2011. These calculations have been augmented as additional information became available. The proportion of employees in firms with $\geq 20$ employees is estimated from the 2008 County Business Patterns. 
TABLE 2

DESCRIPTIVE STATISTICS

\begin{tabular}{|c|c|c|c|c|}
\hline \multicolumn{5}{|c|}{2002 to Q1 2010} \\
\hline & SF Center & SF Periphery & MSA Centers & MSA Periphery \\
\hline Mean Population & 790,262 & $3,409,626$ & $1,997,529$ & $2,944,249$ \\
\hline Mean Minimum Wage & $\$ 8.51$ & $\$ 7.18$ & $\$ 6.33$ & $\$ 6.24$ \\
\hline Mean Housing Price & $\$ 671,151$ & $\$ 562,511$ & $\$ 234,796$ & $\$ 211,436$ \\
\hline Mean Housing Sales & 1,840 & 3,608 & 8,448 & 2,820 \\
\hline \multicolumn{5}{|l|}{ All Private } \\
\hline Total Employment & 450,705 & $1,251,662$ & 902,167 & $1,001,598$ \\
\hline Mean Weekly Earnings & $\$ 1,380$ & $\$ 1,143$ & $\$ 1,011$ & $\$ 834$ \\
\hline \multicolumn{5}{|l|}{ Retail } \\
\hline$\%$ Of Private Employment Q1 2010 & $9 \%$ & $13 \%$ & $11 \%$ & $14 \%$ \\
\hline Total Employment & 43,179 & 160,534 & 99,506 & 142,752 \\
\hline Mean Weekly Earnings & $\$ 761$ & $\$ 662$ & $\$ 563$ & $\$ 524$ \\
\hline \multicolumn{5}{|l|}{ Accommodation \& Food Services } \\
\hline \% Of Private Employment Q1 2010 & $14 \%$ & $9 \%$ & $10 \%$ & $9 \%$ \\
\hline Total Employment & 62,045 & 106,900 & 81,465 & 88,369 \\
\hline Mean Weekly Earnings & $\$ 498$ & $\$ 367$ & $\$ 365$ & $\$ 297$ \\
\hline \multicolumn{5}{|l|}{ Restaurants } \\
\hline$\%$ Of Private Employment Q1 2010 & $10 \%$ & $8 \%$ & $8 \%$ & $8 \%$ \\
\hline Total Employment & 43,805 & 93,469 & 68,500 & 78,583 \\
\hline Mean Weekly Earnings & $\$ 413$ & $\$ 345$ & $\$ 331$ & $\$ 281$ \\
\hline
\end{tabular}

Notes. MSAs include the largest 25 MSAs in the United States with the exception of San Francisco. MSA center is defined as the county that encompasses the urban center of the MSA (see Appendix I). Quarterly earnings and employment data from the Quarterly Census of Employment and Wages, Bureau of Labor Statistics. State and federal minimum wage data from the Department of Labor. Annual county-level population data are from the U.S. Census. Housing data are from Dataquick. 
TABLE 3

EMPLOYMENT TRENDS IN THE BAY AREA AND LARGE MSAS

\begin{tabular}{|c|c|c|c|c|c|c|c|c|}
\hline \multirow[t]{2}{*}{ Log of Employment } & \multicolumn{4}{|c|}{ All Private } & \multicolumn{4}{|c|}{ Retail } \\
\hline & $S F$ & $\begin{array}{c}\text { SF } \\
\text { Periphery }\end{array}$ & $\begin{array}{c}\text { MSA } \\
\text { Centers }\end{array}$ & $\begin{array}{c}\text { MSA } \\
\text { Periphery }\end{array}$ & $S F$ & $\begin{array}{c}S F \\
\text { Periphery }\end{array}$ & $\begin{array}{c}\text { MSA } \\
\text { Centers }\end{array}$ & $\begin{array}{c}\text { MSA } \\
\text { Periphery }\end{array}$ \\
\hline Post & 13.04 & 12.77 & 14.00 & 12.22 & 10.65 & 10.70 & 11.81 & 10.27 \\
\hline Pre & 13.01 & 12.80 & 14.02 & 12.23 & 10.68 & 10.76 & 11.84 & 10.29 \\
\hline \multirow{5}{*}{$\begin{array}{l}\text { Diff } \\
\text { Diff-in-Diff } \\
\text { Diff-in-Diff-in-Diff }\end{array}$} & $3.4 \%$ & $-3.0 \%$ & $-2.2 \%$ & $-1.5 \%$ & $-2.6 \%$ & $-6.2 \%$ & $-3.4 \%$ & $-2.3 \%$ \\
\hline & & $6.5 \%$ & & $-0.8 \%$ & & $3.7 \%$ & & $-1.1 \%$ \\
\hline & & & & $7.2 \%$ & & & & $4.7 \%$ \\
\hline & \multicolumn{4}{|c|}{ Accommodation \& Food Services } & \multicolumn{4}{|c|}{ Restaurants } \\
\hline & $S F$ & $\begin{array}{c}S F \\
\text { Periphery }\end{array}$ & $\begin{array}{c}\text { MSA } \\
\text { Centers }\end{array}$ & $\begin{array}{c}\text { MSA } \\
\text { Periphery }\end{array}$ & $S F$ & $\begin{array}{c}S F \\
\text { Periphery }\end{array}$ & $\begin{array}{c}\text { MSA } \\
\text { Centers }\end{array}$ & $\begin{array}{c}\text { MSA } \\
\text { Periphery }\end{array}$ \\
\hline Post & 11.09 & 10.37 & 11.64 & 9.84 & 10.75 & 10.24 & 11.48 & 9.75 \\
\hline Pre & 11.02 & 10.31 & 11.60 & 9.79 & 10.66 & 10.18 & 11.44 & 9.69 \\
\hline Diff & $7.2 \%$ & $5.5 \%$ & $4.0 \%$ & $5.3 \%$ & $9.1 \%$ & $6.6 \%$ & $4.8 \%$ & $5.9 \%$ \\
\hline Diff-in-Diff & & $1.7 \%$ & & $-1.2 \%$ & & $2.5 \%$ & & $-1.0 \%$ \\
\hline Diff-in-Diff-in-Diff & & & & $2.9 \%$ & & & & $3.6 \%$ \\
\hline \multirow[t]{2}{*}{ Log of Earnings } & \multicolumn{4}{|c|}{ All Private } & \multicolumn{4}{|c|}{ Retail } \\
\hline & $S F$ & $\begin{array}{c}S F \\
\text { Periphery }\end{array}$ & $\begin{array}{c}\text { MSA } \\
\text { Centers }\end{array}$ & $\begin{array}{c}\text { MSA } \\
\text { Periphery }\end{array}$ & $S F$ & $\begin{array}{c}\text { SF } \\
\text { Periphery }\end{array}$ & $\begin{array}{c}\text { MSA } \\
\text { Centers }\end{array}$ & $\begin{array}{c}\text { MSA } \\
\text { Periphery }\end{array}$ \\
\hline Post & 7.24 & 7.03 & 6.88 & 6.74 & 6.61 & 6.42 & 6.29 & 6.23 \\
\hline Pre & 7.22 & 7.02 & 6.87 & 6.74 & 6.64 & 6.51 & 6.35 & 6.30 \\
\hline Diff & $2.2 \%$ & $1.1 \%$ & $1.1 \%$ & $-0.4 \%$ & $-3.2 \%$ & $-8.8 \%$ & $-6.5 \%$ & $-6.8 \%$ \\
\hline Diff-in-Diff & & $1.0 \%$ & & $1.5 \%$ & & $5.6 \%$ & & $0.2 \%$ \\
\hline \multirow[t]{3}{*}{ Diff-in-Diff-in-Diff } & & & & $-0.5 \%$ & & & & $5.4 \%$ \\
\hline & \multicolumn{4}{|c|}{ Accommodation \& Food Services } & \multicolumn{4}{|c|}{ Restaurants } \\
\hline & $S F$ & $\begin{array}{c}\text { SF } \\
\text { Periphery }\end{array}$ & $\begin{array}{c}\text { MSA } \\
\text { Centers }\end{array}$ & $\begin{array}{c}M S A \\
\text { Periphery }\end{array}$ & $S F$ & $\begin{array}{c}\text { SF } \\
\text { Periphery }\end{array}$ & $\begin{array}{c}\text { MSA } \\
\text { Centers }\end{array}$ & $\begin{array}{c}\text { MSA } \\
\text { Periphery }\end{array}$ \\
\hline Post & 6.23 & 5.88 & 5.88 & 5.73 & 6.03 & 5.83 & 5.79 & 5.68 \\
\hline Pre & 6.21 & 5.89 & 5.88 & 5.74 & 6.02 & 5.84 & 5.79 & 5.69 \\
\hline Diff & $1.9 \%$ & $-1.1 \%$ & $-0.5 \%$ & $-1.2 \%$ & $1.2 \%$ & $-0.3 \%$ & $-0.4 \%$ & $-0.5 \%$ \\
\hline Diff-in-Diff & & $3.0 \%$ & & $0.7 \%$ & & $1.5 \%$ & & $0.1 \%$ \\
\hline Diff-in-Diff-in-Diff & & & & $2.2 \%$ & & & & $1.4 \%$ \\
\hline
\end{tabular}

Notes. Post is January 2008 to March 2010. Pre is January 2002 to December 2007. Diff refers to the difference (Post - Pre) in each of the four geographic groups. Diff-in-Diff is Diff of center minus Diff of periphery, in SF and other MSAs. Diff-in-Diff-inDiff is Diff-in-Diff of SF minus Diff-in-Diff of Other MSAs. Multi-county estimates are weighted by county population. Earnings refer to average weekly earnings. All series are seasonally adjusted. Original quarterly data is from the Quarterly Census of Employment and Wages, Bureau of Labor Statistics. 
TABLE 4A

THE EFFECT OF SAN Francisco HeALTH CARE SECURITy ORDINANCE ON EMPLOYMENT
(1)
(2)
(3)
(4)
(5)
(6)
(7)
(8)

Log of Employment

\begin{tabular}{|c|c|c|c|c|c|c|c|c|}
\hline \multicolumn{9}{|l|}{ All Private } \\
\hline Employment Effect & 0.063 & 0.051 & 0.060 & 0.025 & 0.065 & 0.048 & 0.019 & 0.003 \\
\hline Conventional SE & $(0.003)$ & $(0.006)$ & $(0.014)$ & $(0.002)$ & $(0.009)$ & $(0.013)$ & $(0.016)$ & $(0.007)$ \\
\hline $92 \%$ CT Lower Bound & 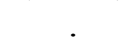 & . & 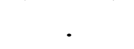 & $\cdot$ & 0.029 & 0.019 & 0.007 & -0.001 \\
\hline 92\% CT Upper Bound & $\cdot$ & . & . & & 0.130 & 0.111 & 0.045 & 0.008 \\
\hline \multicolumn{9}{|l|}{ Retail } \\
\hline Employment Effect & 0.033 & 0.050 & -0.005 & 0.016 & 0.031 & 0.022 & -0.003 & 0.002 \\
\hline Conventional SE & $(0.009)$ & $(0.015)$ & $(0.008)$ & $(0.004)$ & $(0.012)$ & $(0.021)$ & $(0.019)$ & $(0.008)$ \\
\hline $92 \%$ CT Lower Bound & . & 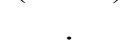 & - & 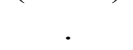 & -0.028 & -0.017 & -0.019 & -0.003 \\
\hline 92\% CT Upper Bound & & . & • & . & 0.138 & 0.070 & 0.027 & 0.014 \\
\hline \multicolumn{9}{|c|}{ Accommodation \& Food Services } \\
\hline Employment Effect & 0.021 & 0.003 & 0.009 & -0.035 & 0.004 & -0.005 & -0.024 & 0.007 \\
\hline Conventional SE & $(0.003)$ & $(0.006)$ & $(0.005)$ & $(0.013)$ & $(0.009)$ & $(0.009)$ & $(0.020)$ & $(0.009)$ \\
\hline $92 \%$ CT Lower Bound & . & . & 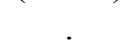 & & -0.039 & -0.026 & -0.040 & 0.001 \\
\hline 92\% CT Upper Bound & • & • & - & . & 0.088 & 0.026 & -0.005 & 0.015 \\
\hline \multicolumn{9}{|l|}{ Restaurants } \\
\hline Employment Effect & 0.022 & 0.002 & 0.018 & 0.002 & 0.008 & 0.003 & -0.001 & 0.003 \\
\hline Conventional SE & $(0.002)$ & $(0.006)$ & $(0.004)$ & $(0.005)$ & $(0.010)$ & $(0.013)$ & $(0.009)$ & $(0.009)$ \\
\hline 92\% CT Lower Bound & . & . & • & & -0.036 & -0.015 & -0.015 & -0.002 \\
\hline $92 \%$ CT Upper Bound & . & . & . & & 0.108 & 0.044 & 0.019 & 0.010 \\
\hline \multicolumn{9}{|l|}{ Controls: } \\
\hline San Francisco MSA Only & $\mathrm{Y}$ & $\mathrm{Y}$ & $\bar{Y}$ & $\mathrm{Y}$ & & & & \\
\hline Pre-period 2002-2007 & $\mathrm{Y}$ & & $\mathrm{Y}$ & & Y & & Y & \\
\hline Pre-period 2006-2007 & & Y & & $\mathrm{Y}$ & & Y & & $\mathrm{Y}$ \\
\hline Linear Time Trend & & & $\mathrm{Y}$ & $\mathrm{Y}$ & & & $\mathrm{Y}$ & $\mathrm{Y}$ \\
\hline
\end{tabular}

Notes. Employment effects are the regression coefficients $\alpha$ associated with the treatment dummy, and outcomes and controls in all regressions are spatially differenced (center minus periphery). All regressions include MSA fixed effects, quarter fixed effects, minimum wage controls, population controls, seasonal controls, and housing controls including sales and price variables and one year lags. Confidence intervals are calculated using the Conley-Taber estimator. Conventional standard errors are reported in parentheses. In specifications 1-4 conventional standard errors are heteroscedasticity and autocorrelation robust (7 quarter lag structure). In specifications 5-8 conventional standard errors are clustered at the MSA level. Quarterly employment and earnings data is from the Quarterly Census of Employment and Wages, Bureau of Labor Statistics. County population estimates from the U.S. Census. Housing data is from Dataquick. 
TABLE 4B

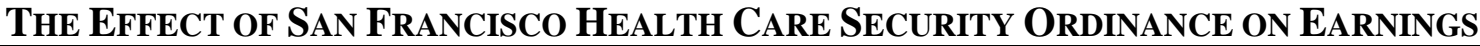
(1)
(2)
(3)
(4)
(5)
(6)
(7)
(8)

Log of Earnings

\begin{tabular}{|c|c|c|c|c|c|c|c|c|}
\hline \multicolumn{9}{|l|}{ All Private } \\
\hline Earnings Effect & 0.006 & -0.040 & 0.059 & 0.004 & -0.014 & -0.012 & -0.027 & -0.003 \\
\hline Conventional SE & $(0.005)$ & $(0.020)$ & $(0.020)$ & $(0.017)$ & $(0.007)$ & $(0.010)$ & $(0.009)$ & $(0.005)$ \\
\hline $92 \%$ CT Lower Bound & . & . & . & & -0.039 & -0.034 & -0.038 & -0.007 \\
\hline 92\% CT Upper Bound & . & . & . & & 0.023 & 0.015 & -0.005 & 0.004 \\
\hline \multicolumn{9}{|l|}{ Retail } \\
\hline Earnings Effect & 0.031 & -0.053 & -0.005 & -0.074 & 0.037 & 0.050 & 0.036 & 0.015 \\
\hline Conventional SE & $(0.008)$ & $(0.012)$ & $(0.010)$ & $(0.009)$ & $(0.008)$ & $(0.008)$ & $(0.010)$ & $(0.009)$ \\
\hline $92 \%$ CT Lower Bound & . & . & . & & 0.011 & 0.026 & 0.020 & 0.008 \\
\hline $92 \%$ CT Upper Bound & . & . & . & . & 0.077 & 0.100 & 0.058 & 0.028 \\
\hline \multicolumn{9}{|c|}{ Accommodation \& Food Services } \\
\hline Earnings Effect & 0.033 & 0.056 & 0.019 & 0.082 & 0.019 & 0.023 & 0.016 & 0.021 \\
\hline Conventional SE & $(0.003)$ & $(0.007)$ & $(0.005)$ & $(0.010)$ & $(0.008)$ & $(0.008)$ & $(0.013)$ & $(0.007)$ \\
\hline 92\% CT Lower Bound & . & . & . & . & -0.018 & -0.013 & 0.000 & 0.016 \\
\hline $92 \%$ CT Upper Bound & . & . & . & 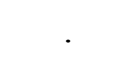 & 0.077 & 0.052 & 0.029 & 0.029 \\
\hline \multicolumn{9}{|l|}{$\underline{\text { Restaurants }}$} \\
\hline Earnings Effect & 0.012 & -0.026 & -0.008 & -0.024 & 0.007 & -0.004 & -0.016 & -0.004 \\
\hline Conventional SE & $(0.004)$ & $(0.004)$ & $(0.005)$ & $(0.003)$ & $(0.008)$ & $(0.007)$ & $(0.012)$ & $(0.007)$ \\
\hline $92 \%$ CT Lower Bound & . & . & . & . & -0.041 & -0.029 & -0.029 & -0.008 \\
\hline 92\% CT Upper Bound & . & . & . & . & 0.087 & 0.030 & -0.001 & 0.009 \\
\hline \multicolumn{9}{|l|}{ Controls } \\
\hline San Francisco MSA Only & $\bar{Y}$ & $\mathrm{Y}$ & $\bar{Y}$ & $\mathrm{Y}$ & & & & \\
\hline Pre-period 2002-2007 & $\mathrm{Y}$ & & $\mathrm{Y}$ & & $\mathrm{Y}$ & & $\mathrm{Y}$ & \\
\hline Pre-period 2006-2007 & & $\mathrm{Y}$ & & Y & & Y & & $\mathrm{Y}$ \\
\hline Linear Time Trend & & & $\mathrm{Y}$ & $\mathrm{Y}$ & & & $\mathrm{Y}$ & Y \\
\hline
\end{tabular}

Notes. Earnings effects are the regression coefficients $\alpha$ associated with the treatment dummy, and outcomes and controls in all regressions are spatially differenced (center minus periphery). All regressions include MSA fixed effects, quarter fixed effects, minimum wage controls, population controls, seasonal controls, and housing controls including sales and price variables and one year lags. Confidence intervals are calculated using the Conley-Taber estimator. Conventional standard errors are reported in parentheses. In specifications 1-4 conventional standard errors are heteroscedasticity and autocorrelation robust (7 quarter lag structure). In specifications 5-8 conventional standard errors are clustered at the MSA level. Quarterly employment and earnings data are from the Quarterly Census of Employment and Wages, Bureau of Labor Statistics. County population estimates from the U.S. Census. Housing data are from Dataquick. 
TABLE 5

FALSIFICATION EXERCISE - “TREATMENT PERIOD” OF 2007

\begin{tabular}{|c|c|c|c|c|c|c|c|c|}
\hline \multirow[b]{3}{*}{$\underline{\text { All Private }}$} & (1) & $(2)$ & (3) & (4) & (5) & (6) & (7) & $(8)$ \\
\hline & \multicolumn{4}{|c|}{ Log of Employment } & \multicolumn{4}{|c|}{ Log of Earnings } \\
\hline & & & & & & & & \\
\hline "Treatment" Effect & 0.018 & -0.013 & -0.001 & 0.001 & 0.026 & 0.012 & 0.023 & -0.002 \\
\hline Conventional SE & $(0.008)$ & $(0.007)$ & $(0.006)$ & $(0.006)$ & $(0.004)$ & $(0.008)$ & $(0.005)$ & $(0.009)$ \\
\hline 92\% CT Lower Bound & -0.003 & -0.038 & -0.020 & -0.011 & 0.006 & 0.000 & 0.007 & -0.010 \\
\hline 92\% CT Upper Bound & 0.076 & 0.007 & 0.026 & 0.028 & 0.049 & 0.037 & 0.042 & 0.011 \\
\hline$\underline{\text { Retail }}$ & & . & 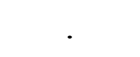 & 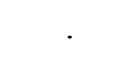 & & & & . \\
\hline 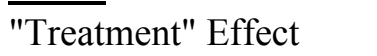 & 0.019 & 0.000 & 0.005 & 0.006 & -0.031 & -0.050 & -0.045 & -0.030 \\
\hline Conventional SE & $(0.011)$ & $(0.010)$ & $(0.007)$ & $(0.006)$ & $(0.005)$ & $(0.007)$ & $(0.005)$ & $(0.007)$ \\
\hline 92\% CT Lower Bound & -0.013 & -0.017 & -0.020 & -0.010 & -0.059 & -0.070 & -0.068 & -0.054 \\
\hline 92\% CT Upper Bound & 0.084 & 0.036 & 0.032 & 0.049 & -0.001 & -0.008 & -0.018 & 0.004 \\
\hline \multicolumn{9}{|c|}{ Accommodation \& Food Services } \\
\hline "Treatment" Effect & -0.002 & -0.007 & 0.002 & -0.001 & -0.013 & -0.030 & -0.020 & -0.014 \\
\hline Conventional SE & $(0.009)$ & $(0.006)$ & $(0.007)$ & $(0.008)$ & $(0.008)$ & $(0.006)$ & $(0.006)$ & $(0.004)$ \\
\hline 92\% CT Lower Bound & -0.029 & -0.020 & -0.013 & -0.012 & -0.043 & -0.048 & -0.039 & -0.024 \\
\hline 92\% CT Upper Bound & 0.060 & 0.017 & 0.033 & 0.031 & 0.021 & 0.003 & 0.012 & 0.003 \\
\hline$\underline{\text { Restaurants }}$ & & . & 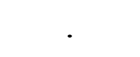 & . & . & & 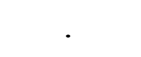 & . \\
\hline "Treatment" Effect & -0.006 & -0.013 & -0.002 & -0.003 & -0.005 & -0.019 & -0.006 & -0.007 \\
\hline Conventional SE & $(0.008)$ & $(0.007)$ & $(0.006)$ & $(0.009)$ & $(0.008)$ & $(0.006)$ & $(0.005)$ & $(0.005)$ \\
\hline 92\% CT Lower Bound & -0.034 & -0.030 & -0.018 & -0.019 & -0.025 & -0.034 & -0.022 & -0.023 \\
\hline 92\% CT Upper Bound & 0.066 & 0.013 & 0.027 & 0.031 & 0.023 & 0.010 & 0.020 & 0.012 \\
\hline \multicolumn{9}{|l|}{ Controls } \\
\hline Pre-period 2002-2007 & $\mathrm{Y}$ & & $\mathrm{Y}$ & & $\mathrm{Y}$ & & $\mathrm{Y}$ & \\
\hline Pre-period 2006-2007 & & Y & & Y & & Y & & $\mathrm{Y}$ \\
\hline Linear Time Trend & & & $\mathrm{Y}$ & $\mathrm{Y}$ & & & $\mathrm{Y}$ & $\mathrm{Y}$ \\
\hline
\end{tabular}

Notes. Employment effects are the regression coefficients associated with a SF*2007 indicator, and outcomes and controls in all regressions are spatially differenced (Center minus Periphery). All regressions include MSA fixed effects, quarter fixed effects, minimum wage controls, population controls, seasonal controls, and housing controls including sales and price variables and one year lags. Confidence intervals are calculated using the Conley-Taber estimator. Heteroscedasticy robust standard errors in parentheses are clustered at the MSA level. Quarterly employment and earnings data are from the Quarterly Census of Employment and Wages, Bureau of Labor Statistics. County population estimates from the U.S. Census. Housing data are from Dataquick. 


\section{TABLE 6}

\section{EMPLOYER SELF-REPORTED EMPLOYMENT AND COMPENSATION RESPONSES TO}

THE HeAlTh CARE SECURITY ORDINANCE

\begin{tabular}{|c|c|}
\hline Reduced employee pay raises or bonuses & $6.0 \%$ \\
\hline Reduced health benefits for some employees & $3.4 \%$ \\
\hline Reduced employer contribution health benefits for dependents & $6.0 \%$ \\
\hline Reduced other employee benefit spending & $4.6 \%$ \\
\hline Reduced any of the above four dimensions of compensation & $14.0 \%$ \\
\hline Reduced number of employees & $8.8 \%$ \\
\hline Reduced hours worked for some employees & $8.1 \%$ \\
\hline Reduced employees or hours & $10.9 \%$ \\
\hline Any of the above changes in compensation or employment & $19.8 \%$ \\
\hline
\end{tabular}

Notes: Reported percentages are weighted by firm size to reflect the proportion of employees affected by each employer response. The data are from 2009 Bay Area Employer Health Benefits Survey. 


\begin{tabular}{|c|c|c|c|c|}
\hline MSA & $\begin{array}{c}\text { Number } \\
\text { of } \\
\text { Counties }\end{array}$ & $\begin{array}{c}\text { Rank } \\
\text { by } \\
\text { Size }\end{array}$ & $\begin{array}{l}\text { Center } \\
\text { City }\end{array}$ & $\begin{array}{l}\text { Center } \\
\text { County }\end{array}$ \\
\hline Atlanta-Sandy Springs-Marietta, GA & 28 & 8 & Atlanta & Fulton \\
\hline Baltimore-Towson, MD & 7 & 19 & Baltimore & Baltimore \\
\hline Boston-Cambridge-Quincy, MA-NH & 7 & 10 & Boston & Suffolk \\
\hline Chicago-Naperville-Joliet, IL-IN-WI & 14 & 3 & Chicago & Cook \\
\hline Cincinnati-Middletown, OH-KY-IN & 15 & 23 & Cincinnati & Hamilton \\
\hline Cleveland-Elyria-Mentor, $\mathrm{OH}$ & 5 & 25 & Cleveland & Cuyahoga \\
\hline Dallas-Fort Worth-Arlington, TX & 12 & 4 & Dallas & Dallas \\
\hline Denver-Aurora-Broomfield, CO & 11 & 20 & Denver & Denver \\
\hline Detroit-Warren-Livonia, MI & 6 & 11 & Detroit & Wayne \\
\hline Houston-Sugar Land-Baytown, TX & 10 & 6 & Houston & Harris \\
\hline $\begin{array}{l}\text { Los Angeles-Long Beach-Santa Ana, } \\
\text { CA }\end{array}$ & 2 & 2 & $\begin{array}{l}\text { Los } \\
\text { Angeles }\end{array}$ & Los Angeles \\
\hline $\begin{array}{l}\text { Miami-Fort Lauderdale-Pompano } \\
\text { Beach, FL }\end{array}$ & 3 & 7 & Miami & Miami-Dade \\
\hline $\begin{array}{l}\text { Minneapolis-St. Paul-Bloomington, } \\
\text { MN-WI }\end{array}$ & 13 & 16 & Minneapolis & Hennepin \\
\hline $\begin{array}{c}\text { New York-Northern New Jersey-Lon! } \\
\text { Island, NY-NJ-PA }\end{array}$ & 23 & 1 & New York & New York \\
\hline $\begin{array}{l}\text { Philadelphia-Camden-Wilmington, } \\
\text { PA-NJ-DE-MD }\end{array}$ & 11 & 5 & Philadelphia & Philadelphia \\
\hline Phoenix-Mesa-Scottsdale, AZ & 2 & 12 & Phoenix & Maricopa \\
\hline Pittsburgh, PA & 7 & 21 & Pittsburgh & Allegheny \\
\hline $\begin{array}{l}\text { Portland-Vancouver-Beaverton, OR- } \\
\text { WA }\end{array}$ & 7 & 22 & Portland & Multnomah \\
\hline $\begin{array}{l}\text { Riverside-San Bernardino-Ontario, } \\
\text { CA }\end{array}$ & 2 & 14 & Riverside & Riverside \\
\hline $\begin{array}{c}\text { Sacramento--Arden-Arcade-- } \\
\text { Roseville, CA }\end{array}$ & 4 & 24 & Sacramento & Sacramento \\
\hline San Francisco-Oakland-Fremont, CA & 5 & 13 & San Francisco & San Francisco \\
\hline Seattle-Tacoma-Bellevue, WA & 3 & 15 & Seattle & King \\
\hline St. Louis, MO-IL & 17 & 17 & St. Louis & St. Louis \\
\hline Tampa-St. Petersburg-Clearwater, FL & 4 & 18 & Tampa & Hillsborough \\
\hline $\begin{array}{l}\text { Washington-Arlington-Alexandria, } \\
\text { DC-VA-MD-WV }\end{array}$ & 22 & 9 & Washington & $\begin{array}{l}\text { District of } \\
\text { Columbia }\end{array}$ \\
\hline
\end{tabular}




\section{Appendix II: Trends in Employment and Wages in San Francisco County, San Francisco Periphery Counties, MSA Center Counties, MSA Periphery Counties: 1990- 2010}

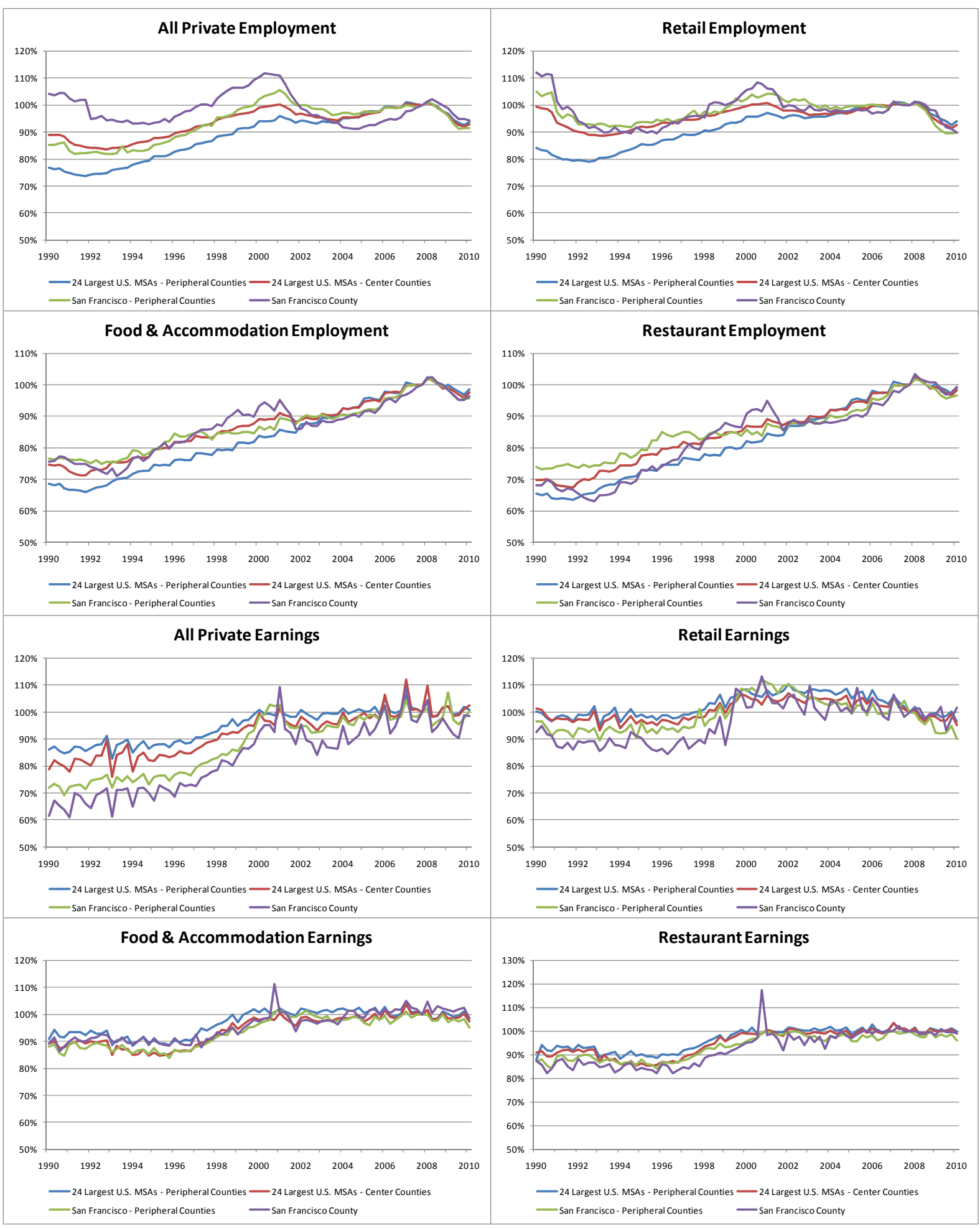

Note: Figures are normalized to Q4 2007, the last period before treatment. 